\title{
Retrospective on Twenty Years of the FDIC-JFSR Bank Research Conference
}

\author{
Haelim Anderson ${ }^{1} \cdot$ Michael Carabello $^{1} \cdot$ Troy Kravitz $^{1}$ (D)
}

Received: 15 November 2021 / Revised: 15 November 2021 / Accepted: 22 November 2021 / Published online: 19 January 2022

This is a U.S. government work and not under copyright protection in the U.S.; foreign copyright protection may apply 2022

\begin{abstract}
The first annual Bank Research Conference was held at the Federal Deposit Insurance Corporation in 2000. The conference has served to disseminate policy-relevant research on issues affecting the banking sector and the stability of the financial system. We evaluate the impact of the conference on policy and research communities, financial regulation, and the banking and finance literature. We examine the topics discussed since the conference's inception and we provide qualitative evidence that the conference has contributed to policy implementation and evaluation. We also examine publication status and citation counts and show that the conference has made an important contribution to research in banking and finance.
\end{abstract}

Keywords Banking $\cdot$ Bank regulation · Bank supervision · Financial stability · Impact study

\section{Introduction}

The annual Bank Research Conference (BRC), introduced in 2000 by the Federal Deposit Insurance Corporation (FDIC) and the Journal of Financial Services Research (JFSR), has grown to serve as a major forum for research economists, legislators, regulators, industry consultants, and industry representatives to critically debate important financial policy issues.

In this paper, we present the evolution of the BRC and its impact on both the policy and research communities. We begin by providing a history of the BRC, highlighting the differences between the BRC and other finance conferences. Then, we describe and examine the

Troy Kravitz

tkravitz@fdic.gov

Haelim Anderson

handerson@fdic.gov

Michael Carabello

mcarabello@fdic.gov

1 Federal Deposit Insurance Corporation, 550 17th Street NW, Washington, DC 20429, USA 
changes in the conference's number of submissions and the rate of acceptance. Next, we present information about BRC participants, including a breakdown of participants by sector and country affiliation, and discuss the conference theme and topics covered. Finally, using quantitative information collected from Google Scholar, we measure the influence that the BRC has had on the banking and finance research literature.

We show that the conference has evolved to serve wider audiences and broader areas of interest. The conference has emphasized specific policy topics directly motivated by the core functions of the FDIC and, especially following the financial crisis of 2008, topics impacting the financial industry more broadly.

Increased outreach, greater attention on banking following the financial crisis, and the expansion of themes discussed during BRC meetings helped attract a large number of submissions and diverse participants representing the academic community and policymakers. The number of submissions increased from fewer than 100 in 2005 to over 400 in recent years. As a result, the acceptance rate for papers submitted for presentation at the conference is under $6 \%$.

We assess the impact of the BRC on the research community by looking at the publication history and citations of presented papers. More than 200 papers presented at the BRC have been published in 55 different peer-reviewed journals. The journals publishing BRC research are well-known for publishing high-quality research addressing financial industry policy issues. In addition, these papers are well cited. More than 80 papers have been cited over 100 times, 16 of which have been cited at least 500 times.

BRC presentations have also helped to inform policymaking. We highlight a few major regulatory rulemakings and describe aspects of selected BRC presentations that preceded those rulemakings. The presentations show that research presented at the BRC was concerned with issues of ongoing and subsequent interest to policymakers.

In Section 2, we discuss the history of the BRC, highlighting how the conference has evolved. In Section 3, we provide summary statistics on participants and research topics. In Section 4, we measure the impact the BRC had on the scholarly literature in finance and banking by analyzing the publication outlets and citation counts of the research papers presented at the BRC. In Section 5, we briefly discuss the connections between presentations at the BRC and important rulemakings. The final section summarizes and concludes.

\section{History of the conference}

The BRC has become a flagship activity of the FDIC's Center for Financial Research (CFR). The Center was created to support and disseminate research on topics important to the FDIC's mission, including bank supervision, deposit insurance, and the resolution of financial institutions. Researchers involved with the creation of the CFR felt there was a clear need to hold a regular conference to help expand the depth and breadth of banking research.

Backed by Donald Powell, the FDIC Chairman at the time, the creation of the CFR was announced at the second meeting of the BRC. Six senior fellows were chosen to help guide the fledgling center: Alan Blinder (Princeton University), Robert Jarrow (Cornell University), Edward Kane (Boston College), Randall Kroszner (University of Chicago), Frederic Mishkin (Columbia University), and Maureen O’Hara (Cornell University).

The founding members of the Center were Arthur Murton (FDIC), Frederick Carns (FDIC), Haluk Ünal (University of Maryland), and Mark Flannery (University of Florida), 
who served as the inaugural Director of the CFR. In a similar spirit to that underlying the creation of the conference, the CFR was founded on the belief that research should help guide policy decisions. Murton, then-FDIC Director of the Division of Insurance and Research, was instrumental in creating both the BRC and CFR. Murton envisioned "academics and industry representatives serv[ing] as sounding boards and provid[ing] valuable feedback on regulatory policies, and regulatory and industry economists help[ing] academics identify relevant research topics" (FDIC 2003).

Since the creation of the CFR, the BRC has been jointly organized by the CFR and the $J F S R$. While the conference was initially envisioned to be a biannual event, FDIC leadership saw how valuable the first meeting was to the banking community and decided to dedicate more resources to make it into an annual conference. Powell, Murton, Carns, and Ünal, as managing editor of the JFSR, led the push to make the BRC into an annual research conference.

The BRC was conceived purely as a research conference. There was never an expectation that a banking agency would use findings from a given paper presented at the conference directly for policy actions. Instead, the BRC reflected the goal that the regulatory process would be informed by research findings and the realization that the time between research findings and policy implementation can be long. The founders envisioned that continuous research would enhance policymakers' understanding of the economics of regulatory issues and help guide the way they developed policy. Although it may be difficult to tie a particular research finding directly to a specific regulation, academic research is inherently embedded in the regulatory process.

In its early years, the BRC was organized around a theme reflecting a specific policy concern, such as "Incorporating Market Information into Financial Supervision" (2000) and "Issues in Securitization and Credit Risk Transfer" (2008). ${ }^{1}$ As the conference developed, organizers began including subgroup topics in addition to the central theme.

\subsection{Conference submissions and acceptance rate}

Judging by paper submissions, there were two main shocks to the number of papers submitted for the BRC. First, the 2008 global financial crisis brought more attention to banking research and led to increased interest in the conference. Submissions roughly doubled pre-crisis to post-crisis (See Fig. 1). As we discuss later in Section 3, the content of the $\mathrm{BRC}$ also changed to reflect the key financial issues revealed by the financial crisis. The conference programs for early years of the BRC were focused on issues of core functional importance to the FDIC, including deposit insurance design, regulatory and supervisory effects on bank behavior, the determinants of bank lending, and the role of market information in evaluating bank activities. During the financial crisis, conference agendas shifted to reflect the broader mission of the FDIC, incorporating more general topics like bank responses to credit risk and consumer borrowing. Sessions devoted to aspects of systemic risk, bank capital, and capital regulation were commonly included on conference agendas post-crisis.

The second shock occurred when the BRC moved towards broader topics of interest to wider audiences and expanded outreach about the conference. This change enabled

\footnotetext{
1 A full list of BRC session titles is included in Appendix 1, and presentations are organized by topic in Appendix 2.
} 


\section{Number of Submissions}

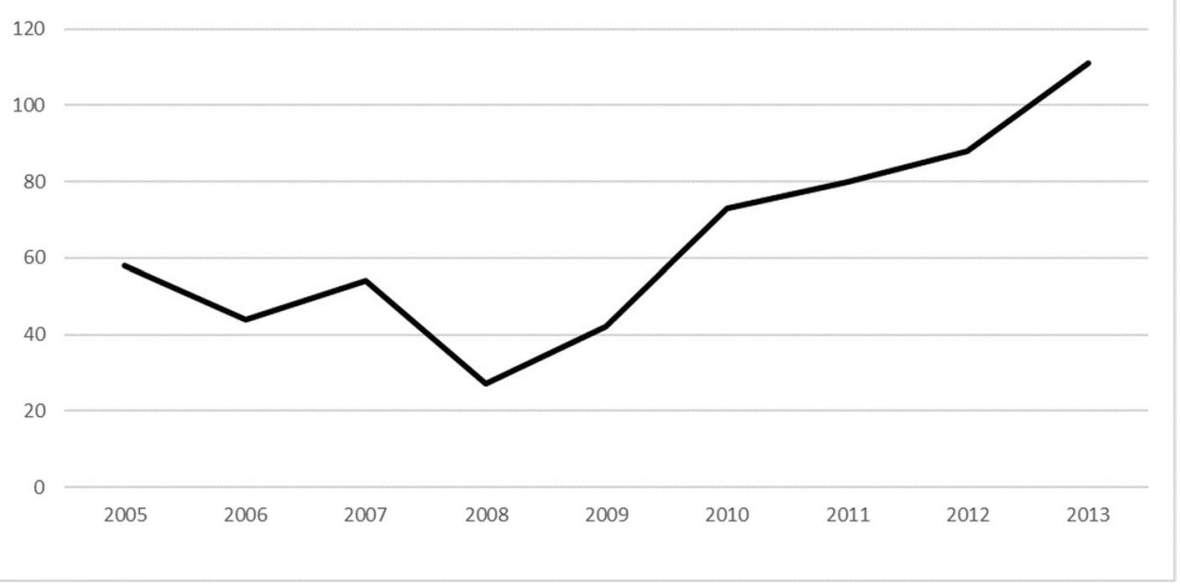

Fig. 1 Conference Submissions Surrounding the Financial Crisis, 2005-2013 (Data on submissions prior to 2005 is unavailable)

the BRC to not only reach a larger, more diverse audience but also to expand the range of research topics presented, establishing the BRC as an attractive conference for many researchers to target when submitting their manuscripts for presentation. Conference organizers more systematically reached out to department chairs in economics and finance and to banking researchers across a variety of institutions, including international and regulatory institutions.

After 2010, paper submissions to the BRC increased four-fold. Despite the increase in submissions, conference organizers did not markedly increase the length of the conference and, instead, kept the number of accepted papers limited so that the conference could remain a two-day event. As a result, the acceptance rate for submitted papers plummeted, and currently averages under $6 \%$ for the last five conferences. The BRC now receives around 400 submissions, of which approximately 20 are accepted for the conference's main program (Fig. 2).

Recently, the conference has added Fast Track sessions in which selected papers are presented in an abbreviated format without discussants. Questions for the presenters take place outside the main conference room after the session has concluded. Typically, multiple conference participants join each presenter to engage in small group discussions about the presentation. To help cultivate nascent banking researchers, the conference now includes a Poster Session where graduate students present their work in the form of a large poster displayed during conference breaks. ${ }^{2}$

Throughout the conference's history, organizers have invited accomplished scholars to deliver keynote addresses. These speakers inform the audience about important developments in the field and highlight the implications for the banking industry. ${ }^{3}$ For example, Raghuram Rajan discussed his work with Douglas Diamond on the role of money in

\footnotetext{
2 The inaugural Poster Session at the 2019 conference was not limited to graduate students.

3 See Appendix 3 for a list of keynote addresses.
} 


\section{Submissions and Acceptances}

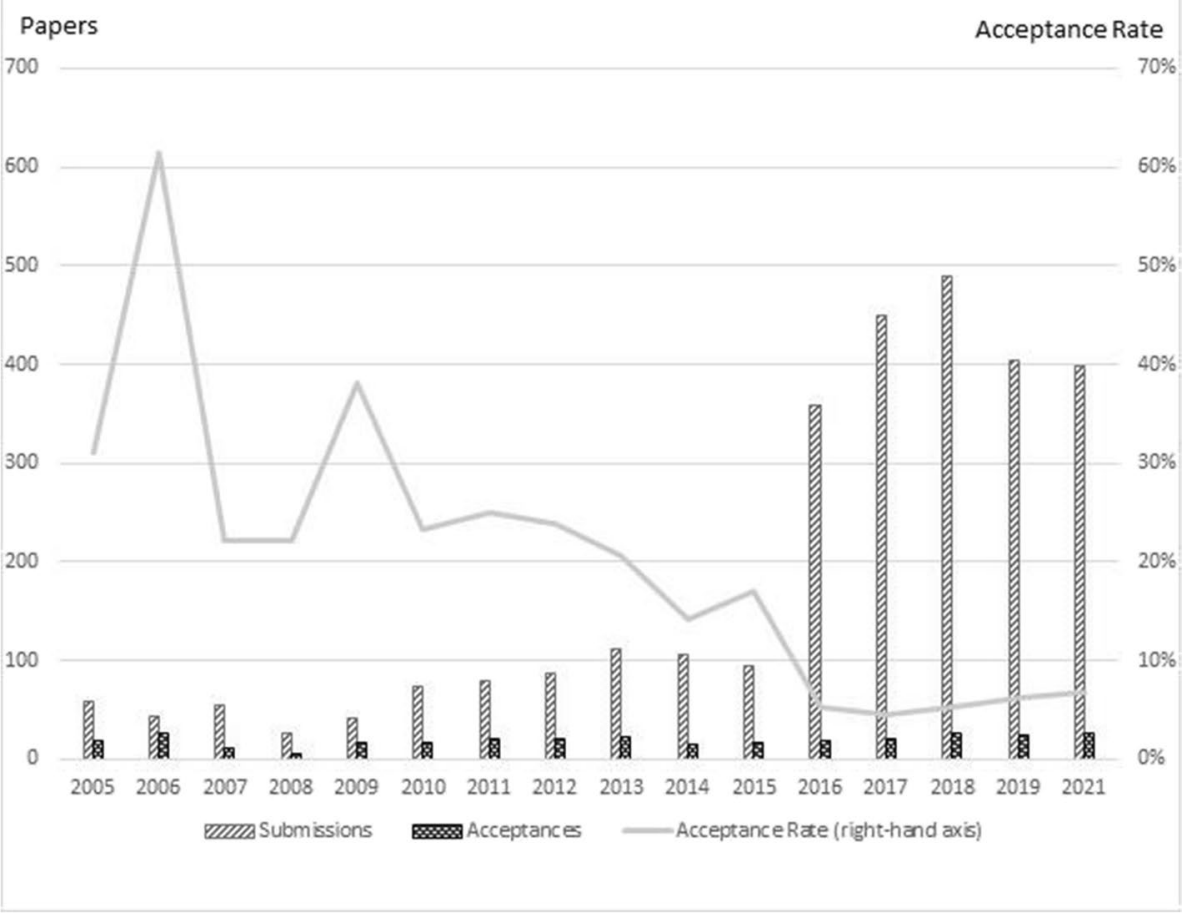

Fig. 2 Paper Submissions and Acceptances, 2005-2021

banking in 2003. Following the financial crisis of 2008, several keynote speakers - such as Anil Kashyap and Douglas Diamond - emphasized the importance of bank regulation and supervision and provided policy recommendations. René Stulz, in 2014, talked about risk-taking and risk management in banks. More recently, Amit Seru highlighted how to conceptualize the regulation of banks when they face competition from fintech companies.

Submissions to the BRC undergo up to three rounds of review. In the first round, the conference organizing committee-made up of FDIC economists and the JFSR Managing Editor-reviews each submission to determine whether it fits within the conference's topics and assess potential interest by the audience. Papers passing this round enter a second review by at least two FDIC staff economists charged with ensuring the quality of the analysis. Among other things, these reviewers consider the theoretical framework, empirical methodology, and suitability of the data. Conference organizers then review the assessments of the staff economists and organize the papers clearing the second-round review into broad topics. Collections of 12 to 18 papers within a broad topic are then reviewed externally.

A unique feature of the BRC is that external, third-round reviewers are also conference discussants and session chairs. Third-round reviewers are selected mainly from the associate editors of the JFSR. To help ensure accepted papers are selected objectively, identifying information is hidden from the papers. These reviewers select two or three papers to be presented at the BRC within a session that they will chair themselves. As session chairs, 


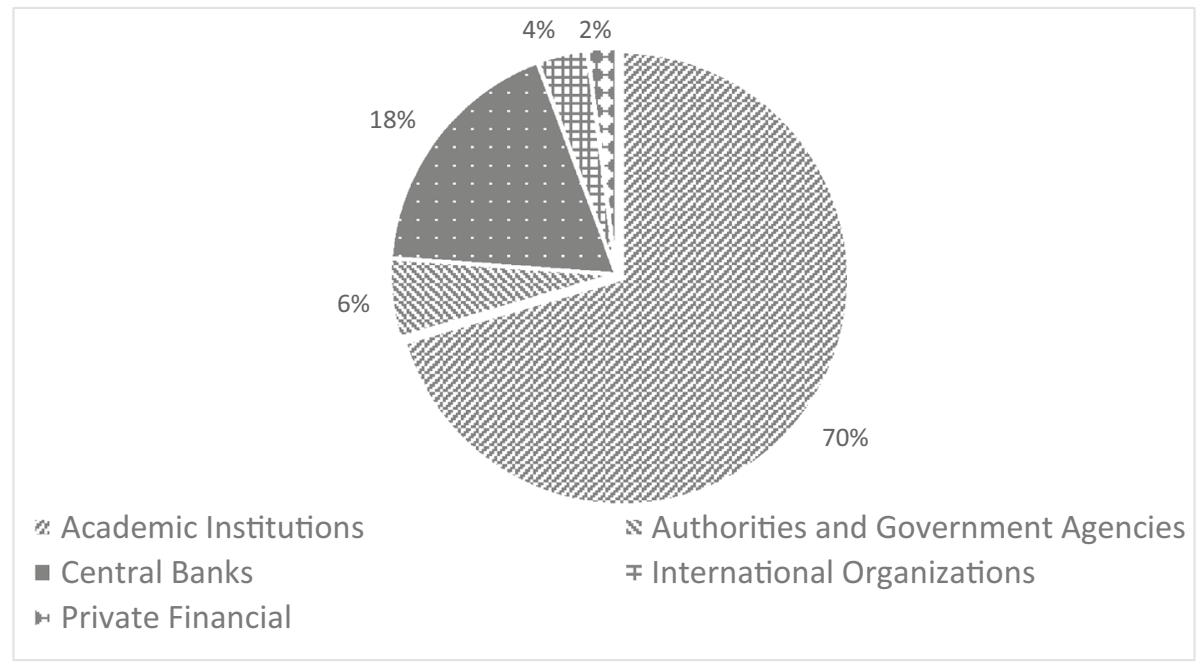

Fig. 3 Bank Research Conference Presenters by Sector, 2000-2019

the external reviewers are already invested in the content of the selected papers. They include these papers in the program because the papers help advance the field's knowledge of important issues. In their capacity as discussants of the chosen papers, third-round reviewers synthesize and critique the presented papers. They also explain how the research papers fit into the broader literature and relate them to each other and to existing work. In this way, third-round reviewers not only provide an additional quality check, but they also present the BRC audience with a big picture overview of the issues studied.

\section{Summary statistics}

From 2000 to 2019, 344 presentations were made across 19 BRCs. ${ }^{4}$ Presentations were of ongoing research projects that economists aimed to publish in professional or academic journals and that were submitted and accepted for inclusion in the conference through the submission and review process.

BRC presenters were mainly from academic institutions (See Fig. 3). Seventy percent of the presenters since the conference's inception represented academic institutions. Participants from central banks, including the Federal Reserve System, account for $17 \%$ of presenters. Six percent of presenters were from authorities and government agencies other than central banks, including the FDIC and the Office of the Comptroller of the Currency. Representatives of international organizations who have presented at the BRC include the World Bank, International Monetary Fund, and Bank of International Settlements. Representatives from private financial organizations also presented at the conference.

\footnotetext{
${ }_{4}$ There was no conference in 2001 as the Bank Research Conference was initially planned to be biennial. Following the success of the first conference, FDIC sponsors committed additional resources to make it an annual conference.

The 2020 Bank Research Conference was cancelled due to the COVID-19 pandemic.
} 


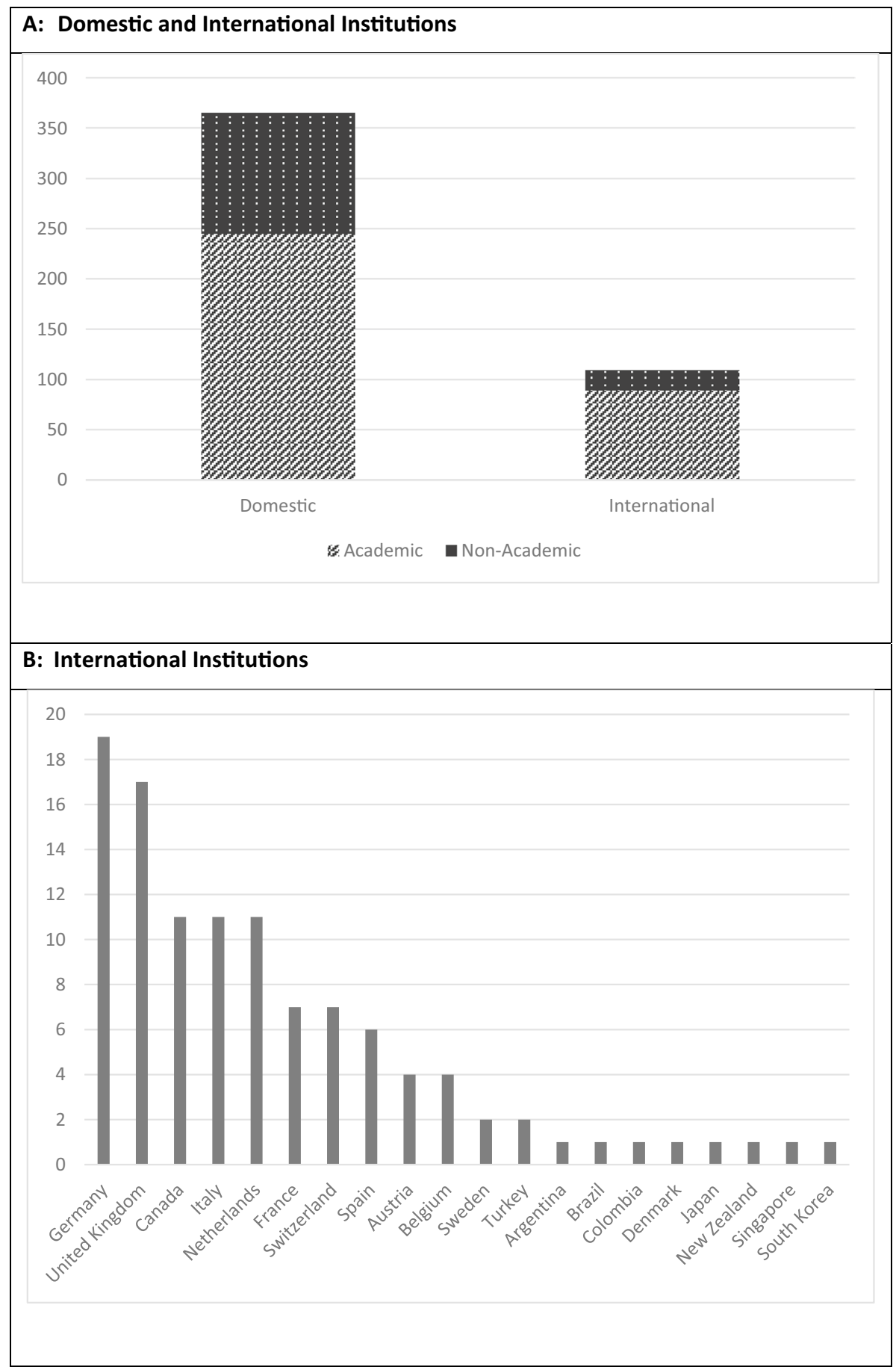

Fig. 4 Presenters' Institutions by Origin 
Table 1 Leading Presenters of Research Papers, 2000-2019

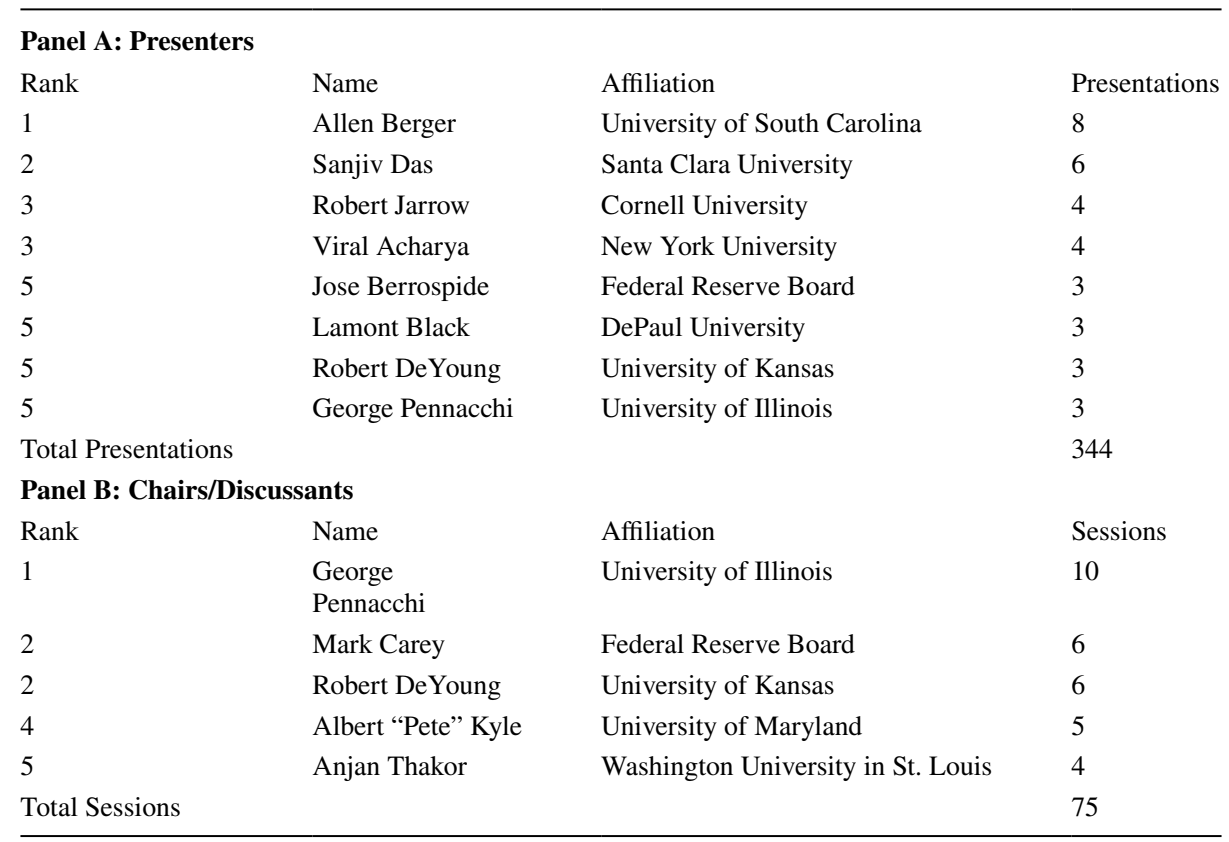

Most presenters were affiliated with U.S. institutions. Approximately two-thirds of U.S.based presenters were from academic institutions, with a further $25 \%$ from central banks and governmental agencies (See Fig. 4). Of presenters from institutions outside the United States, most came primarily from Europe (panel B of Fig. 4). Presenters whose primary affiliation was outside the United States were largely academics.

Table 1 lists the most frequent presenters and session chairs at the BRC. Panel A displays information on the most frequent paper presenters. These presenters are academics who have conducted extensive research on banking topics. Allen Berger has given the most presentations at the BRC, followed by Sanjiv Das, Robert Jarrow, and Viral Acharya.

Panel B provides information on the most frequent session chairs and discussants. Session chairs are accomplished researchers in banking and finance that selected the papers for the conference. They also serve as third-round reviewers and discussants for the sessions they create. George Pennacchi has served as a session chair most frequently, followed by Robert DeYoung and Mark Carey.

Conference agendas included a mix of topics of long-standing general interest and those of more immediate importance. Appendix 1 lists the conferences in reverse chronological order and the session titles for each conference. For the most part, each session featured three or fewer presentations. Appendix 2 categorizes each presentation within one of sixteen broad research topics. Table 2 displays the frequency of each research topic by year. ${ }^{5}$ Some topics continue to be important at the BRC. For instance, "Lending," "Capital," and "Credit Risk" appear consistently throughout the conference's history. ("Regulation/

\footnotetext{
5 Similar results are obtained by charting the frequency of identifying keywords used in the titles of conference presentations.
} 


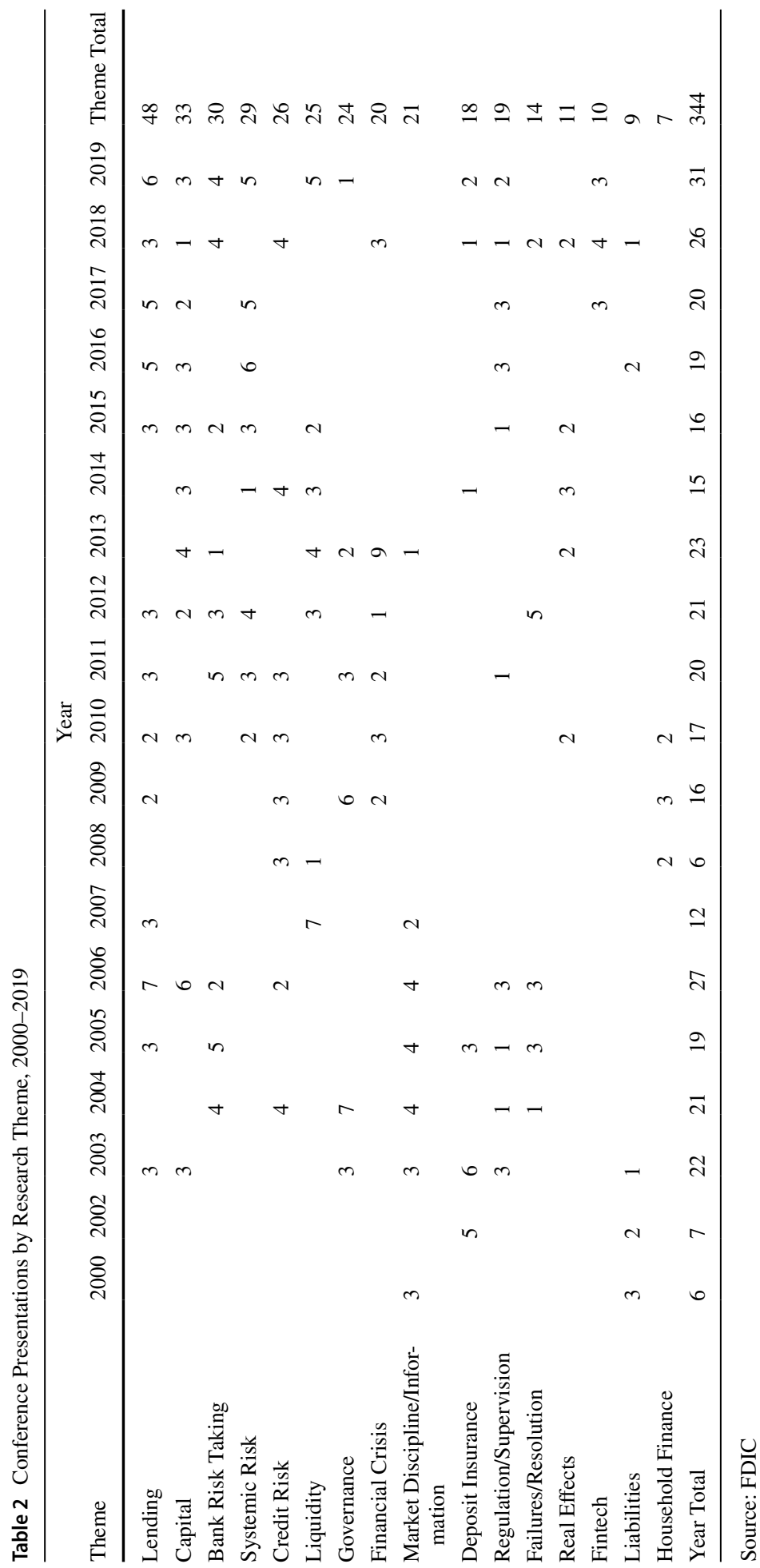


Table 3 Conference Presentations by Research Theme, Pre-Crisis and PostCrisis

\begin{tabular}{llll}
\hline Theme & $2000-2008$ & $2009-2019$ & Total \\
\hline Lending & 16 & 32 & 48 \\
Capital & 9 & 24 & 33 \\
Bank Risk Taking & 11 & 19 & 30 \\
Systemic Risk & - & 29 & 29 \\
Credit Risk & 9 & 17 & 26 \\
Liquidity & 8 & 17 & 25 \\
Governance & 10 & 14 & 24 \\
Financial Crisis & - & 20 & 20 \\
Market Discipline/Information & 20 & 1 & 21 \\
Deposit Insurance & 14 & 4 & 18 \\
Regulation/Supervision & 8 & 11 & 19 \\
Failures/Resolution & 7 & 7 & 14 \\
Real Effects & - & 11 & 11 \\
Fintech & - & 10 & 10 \\
Liabilities & 6 & 3 & 9 \\
Household Finance & 2 & 5 & 7 \\
Period Total & 120 & 224 & 344 \\
\hline
\end{tabular}

Source: FDIC

Supervision" and "Governance" also appear throughout the BRC's history, though less commonly.) "Bank Risk Taking" bookends the financial crisis, suggesting that organizers and presenters actively discussed concerns about bank behavior before 2007. Conferences with greater emphasis on "Bank Risk Taking" in the pre-crisis years also focused on "Market Discipline/Information." Conferences from 2008 to 2010 featured themes related to "Household Finance." At the 2017 BRC, "fFintech" emerged as an active area of research.

The financial crisis altered the financial system in many ways. These changes are reflected in the presentations at the BRC. In Table 3, we divide the history of BRC presentations into a pre-crisis period from 2000 through 2008 and a post-crisis period from 2009 to $2019 .{ }^{6}$ Perhaps owing to interest at the time in using market discipline to supplement traditional supervisory methods, "Market Discipline/Information" was the most prominent theme of BRC presentations during the pre-crisis years, yet it disappeared almost entirely from post-crisis conferences. This may reflect the failure of market discipline to prevent or significantly mitigate the impact of the financial crisis. ${ }^{7}$ Conversely, "Financial Crisis," "Real Effects," and "Systemic Risk" emerged as active areas of research post-crisis. Presentations related to "Financial Crisis" reflected a desire to understand the impetus for the crisis, while those on "Real Effects" underscored a desire to understand the implications of the crisis. The financial crisis showed clearly that turbulence at financial firms can impose real and lasting harm to the rest of the economy. With the growth of "Systemic Risk" as a topic of study, researchers were seeking both an early-warning indicator of potential broad

\footnotetext{
${ }^{6}$ Presentations from 2008 were submitted in the spring and selected in the summer, before the collapse of Lehman Brothers.

7 Hett and Schmidt (2017), for example, find that market discipline deteriorated over the course of the crisis following the rescue of Bear Stearns.
} 
financial distress and a means to gauge the success of attempts to control such risk. Given the role that capital played in the financial crisis, "Capital" was a pervasive theme throughout the post-crisis years of the BRC.

The financial crisis of 2008 increased the need of researchers and policymakers to understand the role of bank regulation and supervision while evaluating new rules for the banking sector and economy. Consequently, more papers were presented on topics related to household finance from 2008 to 2010 , which is not surprising given that the crisis had a considerable impact on households. ${ }^{8}$ These papers attempted to understand the impact of the financial crisis on household debt and credit demand.

Governance issues loomed large during the crisis and throughout its aftermath. Commentators partly attributed the economic distress to misaligned incentives within financial institutions (Faulkender et al. (2010)). The 2008 Troubled Asset Relief Program (TARP) Capital Purchase Program included standardization and restrictions on executive compensation. ${ }^{9}$ These senior executive officer compensation restrictions for companies participating in the Capital Purchase Program included clawback provisions for compensation derived from materially inaccurate statements, "golden parachute" blackout periods, and tax deduction limitations. ${ }^{10}$

The BRC's 2009 keynote address was delivered on this topic by Kenneth Feinberg, Special Master for Executive Compensation, and the conference hosted dedicated sessions on executive compensation and inside debt in 2011 and 2013, respectively. In these sessions, presenters studied how the structure of compensation induced risk-taking within financial institutions, identified potential sources of compensation risk, and described its effect on bank default. ${ }^{11}$ The presenters highlighted the important role that deferral and clawback provisions may play in addressing excessive risk taking.

Finally, with the introduction of new technologies, such as blockchain and peer-to-peer lending platforms, scholarly research evolved to understand how these technologies were changing the financial industry. Consequently, the conference began featuring presentations on fintech topics.

\section{Impact of the Bank Research Conference on the scholarly literature}

To quantify the impact of the BRC on banking research, we examined whether papers presented at the conference were ultimately published in peer-reviewed journals. A total of 344 papers have been presented at the BRC since its inception. We found publication information for 226 of those papers, of which a few are forthcoming. ${ }^{12}$

Papers presented at the BRC have been published in 55 different journals. Table 4 lists the most common journals that published research presented at the BRC. Many journals

\footnotetext{
${ }^{8}$ In 2012, the FDIC launched a Consumer Research Symposium focused on research in consumer finance.

9 The Emergency Economic Stabilization Act of 2008, Pub. L. No. 110-343 (2008), available at https:// www.govinfo.gov/content/pkg/BILLS-110hr1424enr/pdf/BILLS-110hr1424enr.pdf.

10 See Bachelder (2008).

11 See Bennett et al. (2015), DeYoung et al. (2013), Erkens et al. (2012), Fahlenbrach and Stulz (2011), Srivastav et al. (2018), Thanassoulis (2012) (presented as "Bankers' Pay Structure and Risk"), Tzioumisa and Geeb (2013), and Vallascas and Hagendorff (2013).

12 The process is often complicated as papers sometimes change titles during the publication process. Rarely, too, authors are added or removed.
} 
Table 4 Most Common Publications for Papers Presented at the Bank Research Conference

\begin{tabular}{ll}
\hline Journal & Publications \\
\hline Journal of Financial Services Research & 36 \\
Review of Financial Studies & 27 \\
Journal of Financial Economics & 24 \\
Journal of Banking and Finance & 15 \\
Journal of Finance & 14 \\
Journal of Financial Intermediation & 12 \\
Journal of Financial and Quantitative Analysis & 9 \\
Journal of Financial Stability & 8 \\
Journal of Monetary Economics & 7 \\
Journal of Money, Credit, and Banking & 6 \\
Other Journals & 68 \\
\hline
\end{tabular}

Source: FDIC

Table 5 Number of Presented Papers Published in Various Journals by Year

\begin{tabular}{|c|c|c|c|c|}
\hline \multirow[t]{2}{*}{ Journal } & \multicolumn{4}{|c|}{ Publication Year } \\
\hline & $2000-2005$ & 2006-2010 & $2011-2015$ & 2016-2021 \\
\hline Journal of Financial Services Research & 13 & 11 & 6 & 6 \\
\hline Review of Financial Studies & & 4 & 5 & 18 \\
\hline Journal of Financial Economics & & 6 & 9 & 9 \\
\hline Journal of Banking \& Finance & & 5 & 5 & 5 \\
\hline Journal of Finance & 1 & 3 & 5 & 5 \\
\hline Journal of Financial Intermediation & & 4 & 3 & 5 \\
\hline Journal of Financial and Quantitative Analysis & & & 4 & 5 \\
\hline Journal of Financial Stability & & 1 & 4 & 3 \\
\hline Journal of Monetary Economics & & 3 & 1 & 3 \\
\hline Journal of Money, Credit, and Banking & & 2 & 3 & 1 \\
\hline Review of Finance & & & 1 & 4 \\
\hline Review of Corporate Finance Studies & & & & 4 \\
\hline American Economic Review & & 1 & 1 & 1 \\
\hline International Journal of Central Banking & & 1 & 1 & 1 \\
\hline Journal of Corporate Finance & & & 2 & 1 \\
\hline Journal of Accounting and Economics & & 1 & & 1 \\
\hline Journal of Accounting Research & & & & 2 \\
\hline Management Science & & & & \\
\hline
\end{tabular}

Source: FDIC

on this list are known for publishing high-quality research addressing financial industry policy issues. The most common journal of publication is the JFSR, with 36 publications, followed by the Review of Financial Studies (RFS), with 27, and the Journal of Financial Economics (JFE), with 24.

In the early years of the BRC, the JFSR occasionally dedicated special issues to presentations at the conference. For example, in 2001, the JFSR published a special issue on 
market discipline in banking following the BRC meeting on the same topic. Six presentations from the BRC were featured in this issue. When the JFSR published a special issue on "Basel II: Challenges for Implementation," five of the presentations at the BRC were included. Five papers presented at the BRC also made up the 2012 JFSR special issue for the 10th FDIC/JFSR Bank Research Conference.

Table 5 shows that although the JFSR was the primary outlet for papers presented in the early years of the conference, BRC research garnered the attention of other outlets after the financial crisis. This is possibly due to greater interest in banking research among general interest journals. Between 2011 and 2015, the JFE was the primary outlet for papers presented at the conference. By 2016, the JFE remained a common outlet, but the RFS had supplanted it as the most common journal of publication for papers presented at the BRC.

We compiled citation count data for published papers using Google Scholar. Judging by these data, research presented at the BRC is valued highly within the banking and finance profession. More than 80 papers have been cited over 100 times, 16 of which have been cited at least 500 times. Table 6 presents the ten most-cited papers presented at the BRC. It shows that the papers with the most citations attempt to understand the causes of bank risktaking behavior. In particular, three of the four most-cited papers study governance issues.

Naturally, rankings of absolute counts of citations skew in favor of papers presented in the early years of the BRC. To counteract this tendency, we produced annual citation numbers based upon the year of publication for papers published before 2021 (Table 7). We divided each paper's total citations by the number of years since its publication year. Three of the five most-cited papers annually were not among the five most-cited papers overall, suggesting annualized citation data identified papers that quickly established themselves as seminal contributions to the literature.

\section{Connection of the conference to the regulatory process}

Many of the most significant regulations implemented since the financial crisis contain content discussed at the BRC before the rulemakings were implemented. Figure 5 depicts the timing of some consequential regulatory actions dealing with banking and the financial system. Highlighted items in black boxes were identified by the authors as being among the most significant within this sample. ${ }^{13}$ In this section we briefly describe four rulemakings that include content discussed at the BRC before the rule's implementation.

In January 2013, the Consumer Financial Protection Bureau issued a rule to protect consumers from certain types of mortgage lending by requiring that lenders comply with ability-to-repay requirements. ${ }^{14}$ These requirements established documentation requirements for borrower employment, income, assets, and debt obligations. At the 2008 BRC, "Credit Booms and Lending Standards: Evidence from the Subprime Mortgage Market" by Giovanni Dell'Ariccia, Deniz Igan, and Luc Laeven linked the subprime mortgage crisis

\footnotetext{
13 The timeline is not comprehensive as other financial system regulations were promulgated during the period. For more information, see Appendix 2: Selected Federal Agency Actions Affecting Community Banks, 2008-2019 of the 2020 FDIC Community Banking Study, available at https://www.fdic.gov/resou rces/community-banking/cbi-study.html, and the FDIC's list of "Important Banking Laws," available at https://www.fdic.gov/regulations/laws/important/.

14 Consumer Financial Protection Bureau, "Ability-to-Repay and Qualified Mortgage Standards Under the Truth in Lending Act (Regulation Z)," Federal Register 78, No. 20 (January 30, 2013): 6407, https://www. govinfo.gov/content/pkg/FR-2013-01-30/pdf/2013-00736.pdf.
} 


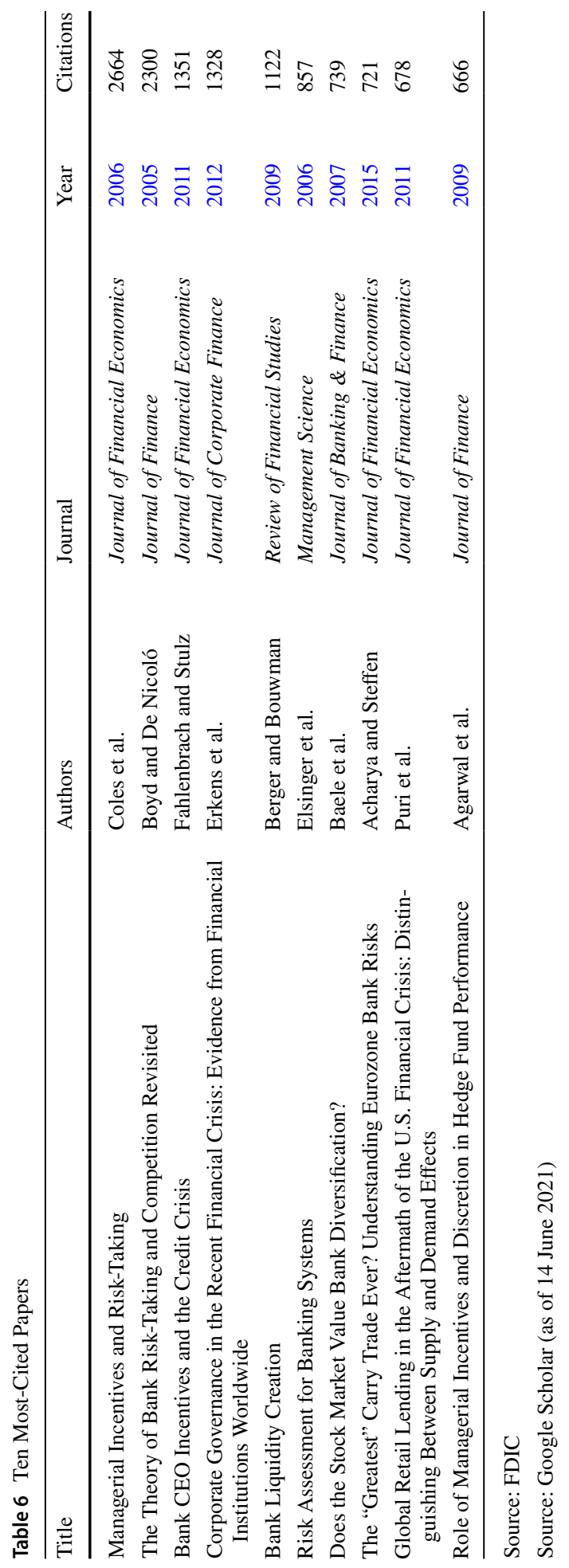




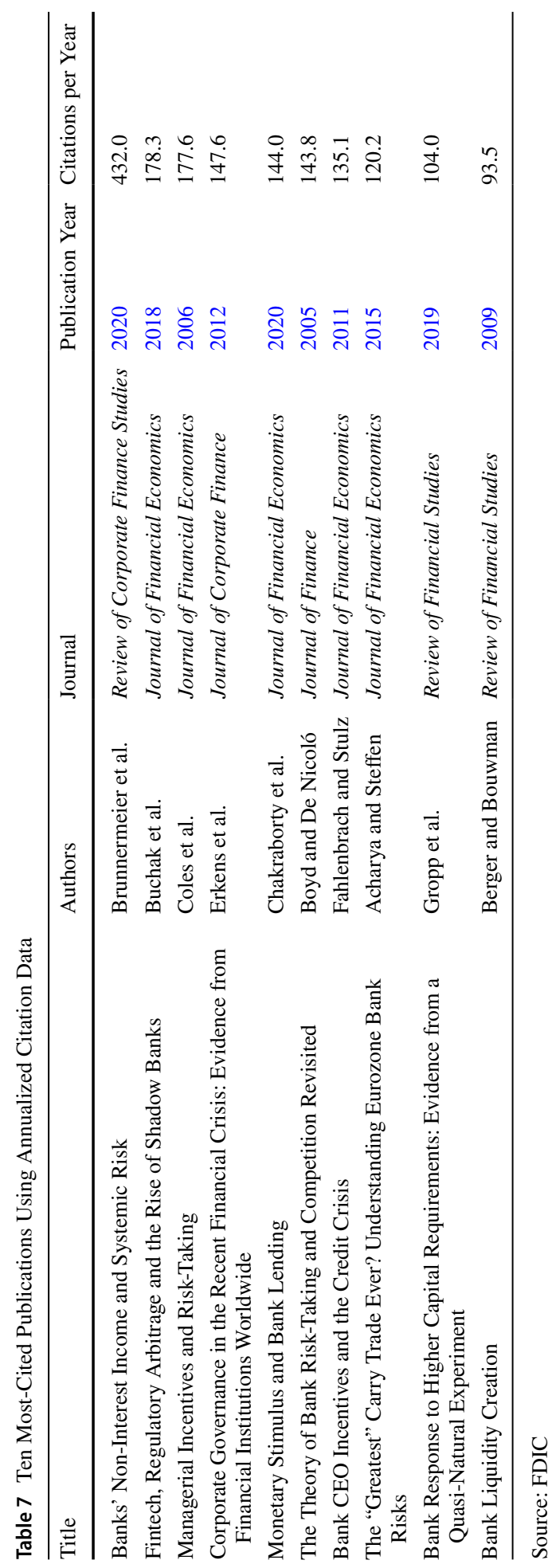




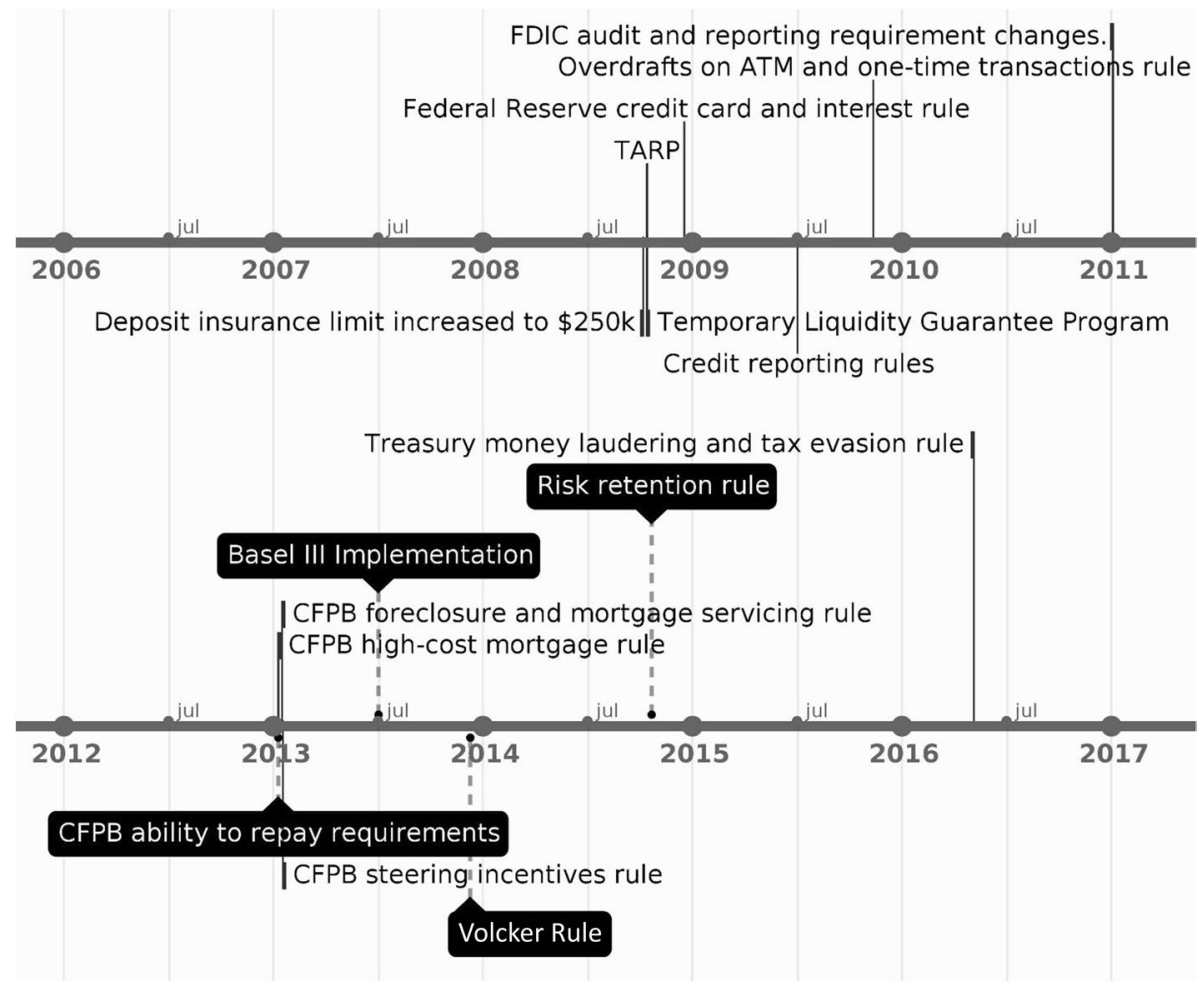

Fig. 5 Timeline of Significant Financial Regulatory Actions, 2008-2016

to a decline in lending standards. The presentation showed that lending standards declined to a greater extent in areas that experienced faster credit growth before the crisis. One year later, illustrating the diversity of academic findings on policy issues, "Where is the Smoking Gun? A Study of Underwriting Standards for U.S. Subprime Mortgages” by Geetesh Bhardwaj and Rajdeep Sengupta, took issue with the claim that underwriting standards deteriorated post-2004. They found no evidence of a dramatic weakening of subprime lending standards using loan-level data.

One of the most significant regulatory changes over the past two decades concerned the implementation of the Basel III risk-based capital framework. ${ }^{15}$ The July 2013 rulemaking increased risk-based capital requirements, tightened the definition of regulatory capital, altered the risk-weights assigned to certain types of credit exposures held by banks, and implemented the statutory prohibition against references to credit ratings in regulation.

15 Federal Reserve System, "Regulatory Capital Rules: Regulatory Capital, Implementation of Basel III, Capital Adequacy, Transition Provisions, Prompt Corrective Action, Standardized Approach for RiskWeighted Assets, Market Discipline and Disclosure Requirements, Advanced Approaches Risk-Based Capital Rule, and Market Risk Capital Rule,’ Federal Register 78, No. 198 (October 11, 2013): 62018, https:// www.govinfo.gov/content/pkg/FR-2013-10-11/pdf/2013-21653.pdf. 
Presentations at the BRC discussed aspects of these issues before the rulemaking. In 2008, "Optimal Credit Risk Transfer, Monitored Finance, and Banks" by Gabriella Chiesa discussed the theoretical design of risk-based capital requirements. Mark Carlson (in work with Hui Shan and Missaka Warusawitharana) presented "Capital Ratios and Bank Lending: A Matched Bank Approach" in 2011, which empirically examined the impact of bank capital ratios on bank loan growth. Also in 2011, "Capital Regulation and Tail Risk" by Enrico Perotti, Lev Ratnovski, and Razvan Vlahu discussed bank responses to risk mitigation through capital regulation and the implications for optimal capital regulation design.

The topic of credit ratings played a prominent role in several BRC presentations, including "The Subprime Credit Crisis of 2007" by Michel G. Crouhy, Robert A. Jarrow, and Stuart M. Turnbull (presented in 2008) on rating agency incentive problems. The 2009 BRC included several presentations related to credit ratings, including "MBS Ratings and the Mortgage Credit Boom"16 by Adam Ashcraft, Paul Goldsmith-Pinkham, and James Vickery who empirically examined the role of credit ratings for subprime mortgages in the financial crisis. Also in 2009, "Credit Rating Accuracy and Incentives" by Robert A. Jarrow and Liheng $\mathrm{Xu}$, and "Credit-Rating Shopping, Selection and the Equilibrium Structure of Ratings" by Francesco Sangiorgi, Jonathan Sokobin, and Chester Spatt considered the microstructure of credit ratings that result in inaccurate ratings. In 2012, Giuliano Iannotta presented "Bank Regulation, Credit Ratings, and Systematic Risk" 17 (with George Pennacchi), arguing that regulations based upon credit ratings can push banks towards systemically risky investments.

Section 619 of the Dodd-Frank Act, more commonly referred to as the Volcker Rule, prohibited banking organizations from undertaking proprietary trading and from sponsoring certain types of hedge funds and private equity funds. ${ }^{18}$ Before the rule's finalization in late 2013, presentations at the 2012 and 2013 BRCs considered the role of trading assets and proprietary trading activities on bank functions and performance. "Banking and Trading" by Arnoud W.A. Boot, and Lev Ratnovski (presented in 2012) discussed banks allocating too much capital to easily scalable proprietary trading activities instead of less scalable relationship lending. "How Does Bank Trading Activity Affect Performance? An Investigation Before and After the Crisis" by Michael R. King, Nadia Massoud, and Keke Song (presented in 2013) described their finding that trading activities were positively correlated with riskiness, negatively correlated with profitability, and associated with greater contribution to systemic risk.

In late 2014, six federal agencies implemented a statutory requirement by jointly approving a risk retention rule requiring securitizers to retain at least $5 \%$ of the credit risk of their securitizations on their balance sheets. ${ }^{19}$ In 2010, "Differences across Originators in CMBS Loan Underwriting" by Lamont K. Black, Chenghuan Sean Chu, Andrew Cohen, and Joseph B. Nichols argued that moral hazard caused by a lack of warehousing risk negatively affects the quality of underwritten loans. Balance sheet lenders, on the other hand, underwrote higher quality loans according to the paper.

Aspects of numerous other regulatory rulemakings were discussed at the BRC before their final approval. In this way, BRC presentations achieved the goal from the BRC's

\footnotetext{
16 Published as "Credit Ratings and Security Prices in the Subprime MSB Market."

17 Published as "Ratings-Based Regulation and Systematic Risk Incentives," with João Santos.

18 Dodd-Frank Wall Street Reform and Consumer Protection Act, U.S. Code 12 (2010) § 1851.

19 Office of the Comptroller of the Currency et al., "Credit Risk Retention," Federal Register 79, No. 247 (December 24, 2014): 77601, https://www.govinfo.gov/content/pkg/FR-2014-12-24/pdf/2014-29256.pdf.
} 
founding to encourage and disseminate research while helping to imbue a deeper understanding of the relevant economics issues throughout the regulatory process.

\section{Conclusion}

The Bank Research Conference was created in 2000 on the belief that research should help inform and guide policy decisions. It has become the flagship activity of the Center for Financial Research since the center's creation in 2003. Given the lag between a manuscript's submission and its final publication, the CFR/BRC's founders hoped policymakers could use research presented at the conference to broaden their understanding of the economics of regulatory issues. Over time, the conference has evolved and become a major forum for policymakers, academics, and other researchers to discuss broader issues regarding the regulation and supervision of financial institutions. The BRC has become one of the leading conferences in the world dedicated to understanding banking-related issues.

In recognition of the 20th anniversary of the BRC, this study provides a brief history of the BRC and an evaluation of its impact. The scope of the BRC has changed during the conference's history, enabling it to tap into broader banking topics for paper submissions and attract a broader audience of conference participants. Acceptance for presentation at the $\mathrm{BRC}$ is highly competitive with an acceptance rate under $6 \%$ over the last five conferences.

Both through keynote speeches and the research topics considered for presentation, the BRC has enhanced policymakers' understanding of regulatory and supervisory issues. Throughout the BRC's history, we observe that key aspects of regulatory and supervisory rules have been discussed in conference presentations prior to and following rulemakings. By disseminating research that has helped policymakers better understand the banking sector and its impact on financial stability, the BRC has helped advance former FDIC Chairman Donald Powell's vision of "original, focused research lead[ing] to sound policy decisions" (FDIC 2003).

The impact of the BRC on the research community can been seen in the many papers that were presented at the conference and subsequently published in leading economics, finance, and banking journals. The breadth of this impact has expanded over time. In the first five years of the BRC, only one journal published multiple papers that were presented at the conference. In the most recent five years, 13 journals have published multiple papers that were presented at the BRC, with seven journals publishing at least five such papers. The quality of the research presented at the BRC is evidenced by many of these publications being highly cited within the research community. Five papers have been cited over 1000 times already, and nine papers are currently averaging over 100 citations per year.

Over its first twenty years, the BRC has succeeded in bringing together leading economists to discuss financial topics and their connection to current policy issues. Growing in stature and scope from its inception, the BRC is poised to continue making important contributions to banking and finance research over the next twenty years.

\section{Appendix 1: Bank Research Conference Sessions, 2000-2019}

1. 19th Annual Bank Research Conference, September 13-14, 2019

a. Price and Quantity Effects of Capital Regulations

b. The Impact of Regulation on Banks 
c. Deposit Insurance and Resolution of Failed Banks

d. Fast Track Session ${ }^{20}$

e. The Effects of Bank Capital and Liquidity Regulation on Bank Lending and Risk Taking

f. Interconnectedness, Systemic Risk, and Policy Implications

g. Externalities in New Financing Platforms

h. Bank Activities and Risk

i. High Yield Debt

j. Poster Session $^{21}$

2. 18th Annual Bank Research Conference, September 6-7, 2018
a. Tradeoffs in Bank Regulation
b. Regulations, Institutions, and Bank Behavior
c. Segmentation of the Lending Markets
d. Stress Spillovers through Banks
e. Fast Track Session
f. The Internal Organization of Bank Holding Companies
g. Managing Default Risk: Competition, Regulation, and Capital
h. FinTech
i. Depositor Reaction to Increased Risk at Banks

3. 17th Annual Bank Research Conference, September 7-8, 2017
a. Quantitative Models of Bank Capital Requirements
b. The Impact of Bank Supervision
c. Stability of Banking Networks
d. Compensation and Risk
e. Runs, Repos, and Reporting
f. Fintech and Traditional Banking
g. Crisis, Policy, and Bank-Credit Supply
h. The Changing Environment and Bank Lending

4. 16th Annual Bank Research Conference, September 8-9, 2016
a. Special Session: Liquidity and Capital Regulation and Their Effects on Systemic Risk
b. Measuring and Understanding Systemic Risk
c. Bank Funding Decisions
d. Capital
e. Supervision
f. Bank Lending

\footnotetext{
${ }^{20}$ Fast Track Sessions include papers that did not fit within other conference sessions. Those papers are presented in a shared panel without moderator discussion.

21 The Poster Session is a presentation of a poster-sized billboard of key points of research papers. Posters are displayed in the conference meeting area for discussion between conference sessions.
} 
g. Central Bank Asset Purchases and the Effect on Bank Credit Formation

5. 15th Annual Bank Research Conference, September 17-18, 2015
a. Bank Capital
b. Macroprudential Regulation
c. Systemic Risk I
d. Systemic Risk II
e. Lending
f. Bank Dividend Policy

6. 14th Annual Bank Research Conference, September 18-19, 2014
a. Liquidity and Credit Risk Management During and After the Crisis
b. Intermediation and the Real Economy
c. Systemic Risk: Sources of Vulnerability
d. Common Shocks and Bond Markets
e. Credit Ratings in Lending and Regulation
f. International Perspectives on Capital Requirements

7. 13th Annual Bank Research Conference, October 25-26, 2013
a. Global Banks and Transmission
b. Financial Stability Theory
c. Crisis Management: Intended and Unintended Consequences
d. Bank Scope and Regulation
e. The Effects of Corporate Taxes on Banking
f. Inside Debt and Bank Risk Taking
g. Real Effects of the Financial Crisis
h. Regulation and Bank Cost of Capital
i. Liquidity-Risk Management
j. Funding Liquidity

8. 12th Annual Bank Research Conference, October 11-12, 2012
a. Systemic Risk
b. Consequences of Government Intervention
c. Resolution of Financial Distress
d. Bank Lending
e. Bank Capital
f. Systemic Risk II
g. Liquidity
h. Bank Behavior

9. 11th Annual Bank Research Conference, September 16-17, 2011
a. Government Support and Bank Behavior
b. Measuring Systemic Risk 

c. Bank Lending During the Crisis
d. Bank Performance during the Crisis
e. Limits to Regulation?
f. Executive Compensation and Bank Risk
g. Information Content in CDS Spreads

10. 10th Annual Bank Research Conference, October 28-29, 2010
a. Reflections on the Financial Crisis
b. Finance and the Real Economy
c. Measuring Systemic Risk
d. Economics of Ratings
e. Bank Lending and Capital
f. Consumer Loan Defaults
g. Bank Capital Adequacy

11. 9th Annual Bank Research Conference, September 17-18, 2009
a. Corporate Governance in the Financial Sector
b. Governance and Bank Lending Behavior
c. Rating Agency Incentives
d. Further Considerations in Incentive Structures
e. Household Finance
f. The Subprime Crisis

12. 8th Annual Bank Research Conference, September 18, 2008
a. Liquidity Crisis, Runs, and Security Design—Lessons from the Collapse of the Auction Rate Municipal Bond Market
b. Optimal Credit Risk Transfer, Monitored Finance, and Banks
c. Laying off Credit Risk: Loan Sales versus Credit Default Swaps
d. Counterparty Risk in Financial Contracts: Should the Insured Worry About the Insurer?
e. Credit Booms and Lending Standards: Evidence from the Subprime Mortgage Market
f. The Subprime Credit Crisis of 07

13. 7th Annual Bank Research Conference. September 20-21, 2007
a. Asset Prices and Liquidity
b. Equity Markets
c. Liquidity Issues
d. Issues in Bank Liquidity
e. Issues in Bank Lending

14. 6th Annual Bank Research Conference, September 13-15, 2006

a. Basel II: Implementation Issues

b. Evaluating Basel II as a Risk Measurement Standard and as Public Policy 
c. Panel Discussion: Regulatory and Bank Implementation of Basel II

d. Basel II: Implementation Issues

e. Resolution Policy and the Cost of Bank Failures

f. JMCB-FDIC Invited Lecture: Searching for a Metric for Financial Stability

g. Credit Risk

h. Bank Risk

i. Banking Practices

j. Bank Risk and Diversification

k. Information and Transparency

15. 5th Annual Bank Research Conference, September 22-23, 2005
a. Deposit Insurance
b. International Banking
c. Emerging Risks
d. JMCB-FDIC Invited Lecture: Is Financial Globalization Beneficial?
e. Loan Pricing and Performance
f. Informational Efficiency of Markets
g. Bank Failures

16. 4th Annual Bank Research Conference, September 17-18, 2004
a. Governance and Managerial Incentives
b. Managerial Actions
c. Invited Paper
d. Hedging
e. Issues in Banking Supervision
f. Issues in Credit Risk
g. International
h. Issues in Banking Performance

17. 3rd Annual Bank Research Conference, September 19-20, 2003
a. Bank Lending
b. Deposit Insurance - Pricing
c. Bank Supervision
d. Risk and Bank Security Prices
e. Managerial Preferences and Bank Performance
f. Invited Paper: Money in a Theory of Banking
g. Deposit Insurance - International Evidence
h. Basel II and Beyond

18. 2nd Annual Bank Research Conference, September 13, 2002
a. Invited Address: Pricing FDIC Insurance Using Reduced Form Credit Risk Models
b. Insurance Fund Design
c. Use of Subordinated-Debt Data in Pricing Deposit Insurance
d. Use of Supervisory Data in Pricing Deposit Insurance 
19. 1st Annual Bank Research Conference, November 9, 2000

a. Setting the Stage: Some Thoughts on Market Discipline

b. Using Data

c. Market Assessments of Value

d. SND Abroad

e. Panel Discussion: Supervisor and Market Analysts: What Should Research Be Seeking?

\section{Appendix 2: Bank Research Conference Presentations, by Topic, 2000- 2019}

\section{Bank Risk Taking: Types of and Motivations for Bank Risk}

- Asset Encumbrance, Bank Funding, and Covered Bonds. Presented by Toni Ahnert, Bank of Canada, in 2015.

- Bailouts, Contagion, and Bank Risk-Taking. Presented by Giovanni Dell 'Ariccia, International Monetary Fund and CEPR, in 2011.

- Bank Regulation, Credit Ratings, and Systematic Risk. Presented by Giuliano Iannotta, Universita Bocconi, in 2012.

- Bank Risk Taking and Liquidity Creation Following Regulatory Interventions and Capital Support. Presented by Allen N. Berger, University of South Carolina, in 2011.

- Business Complexity and Risk Management: Evidence from Operational Risk Events in U.S. Bank Holding Companies. Presented by Anna Chernobai, Syracuse University, in 2018.

- Capital Regulation and Tail Risk. Presented by Enrico C. Perotti, University of Amsterdam and CEPR, in 2011.

- Controlling Fraud Risk Exposure and Loss. Presented by Sherri Goodman, Capital One, in 2005.

- Credit and Identity Theft. Presented by Charles Kahn, University of Illinois, in 2005.

- The Dark-Side of Banks' Non-Bank Business: Internal Dividends in Bank Holding Companies. Presented by Jonathan Pogach, Federal Deposit Insurance Corporation, in 2018.

- Do Banks Hedge in Response to the Financial Distress Costs? Presented by Amiyatosh Purnanandam, University of Michigan, in 2004.

- Do Distressed Banks Really Gamble for Resurrection? Presented by Itzhak Ben-David, The Ohio State University, in 2019.

- Does Corporate Income Taxation Affect Securitization? Evidence from OECD Banks. Presented by Di Gong, Tilburg University, in 2013.

- Does Hedging Really Increase Firm Value? Evidence from Oil and Gas-Producing Firms. Presented by Aziz Lookman, Carnegie Mellon University, in 2004.

- Does Increased Shareholder Liability Always Reduce Bank Risk-Taking? Presented by Haelim Anderson, Federal Deposit Insurance Corporation, in 2019.

- The Effects of Capital Requirements on Good and Bad Risk Taking. Presented by N. Aaron Pancost, University of Texas at Austin, in 2018.

- The Effect of TARP on Bank Risk-Taking. Presented by Lamont Black, Board of Governors of the Federal Reserve System, in 2011. 
- Financial Sector Integrity and Emerging Risks in Banking. Presented by João A. C. Santos, Federal Reserve Bank of New York, in 2005.

- The "Greatest" Carry Trade Ever? Understanding Eurozone Bank Risks. Presented by Viral V. Acharya, New York University, in 2012.

- Holding Company Affiliation and Risk: Evidence from the U.S. Banking Sector. Presented by Radoslav Raykov, Bank of Canada, in 2019.

- How Banks Respond to Negative Interest Rates: Evidence from the Swiss Exemption Threshold. Presented by Mike Mariathasan, KU Leuven, in 2018.

- Identity Verification and Fraud Detection. Presented by Darren Baldwin, IBM Entity Analytic Solutions, in 2005.

- The Information Value of Past Losses in Operational Risk. Presented by Filippo Curti, Federal Reserve Bank of Richmond, in 2019.

- Interest Rate Risk and Bank Equity Valuations. Presented by William B. English, Federal Reserve Board, in 2012.

- Regulatory Capital and Earnings Management in Banks: The Case of Loan Sales and Securitizations. Presented by N. Emre Karaoglu, University of Southern California, in 2004.

- Safer Ratios, Riskier Portfolios: Banks' Response to Government Aid. Presented by Ran Duchin, University of Michigan Denis Sosyura, University of Michigan, in 2011.

- Sources of Bank Charter Value. Presented by Frederick T. Furlong Federal Reserve Bank of San Francisco, in 2006.

- The Theory of Bank Risk-Taking and Competition Revisited. Presented by John Boyd, University of Minnesota, in 2004.

- Unconsolidated Subsidiaries, Bank Capitalization, and Risk Taking. Presented by Di Gong, Tilburg University, in 2015.

- Visible and Hidden Risk Factors for Banks. Presented by Til Schuerman, Federal Reserve Bank of New York, in 2006.

\section{Capital: Effects of Bank Capital and Capital Requirements}

- Are Contingent Convertibles Going-Concern Capital? Presented by Franco Fiordelisi, University of Rome III, in 2018

- An Assessment of Basel II Procyclicality in Mortgage Portfolios. Presented by Jesús Saurina, Banco de España, in 2006

- Bank Capital Requirements and Loan Pricing: Loan-Level Evidence from a Macro Prudential Within-Sector Policy. Presented by Bruno Martins, Central Bank of Brazil, in 2014

- Bank Funding Costs and Capital Structure Presented by: Andrew R. Gimber, Bank of England in 2019

- Bank Payout Policy, Performance, and Insider Trading in the Financial Crisis of 20072009. Presented by Peter Cziraki, University of Toronto, in 2015

- Bank Response to Higher Capital Requirements: Evidence from a Natural Experiment. Presented by Reint Gropp, Halle Institute for Economic Research and University of Magdeburg, in 2016

- Banking and Trading. Presented by Arnoud Boot, University of Amsterdam and CEPR, in 2012

- Basel II: A Case for Recalibrating. Presented by Paul Kupiec, Federal Deposit Insurance Corporation, in 2006 
- Basel II: A Contracting Perspective. Presented by Edward Kane, Boston College, in 2006

- Basel II: A Critique of Revised. Presented by Robert Jarrow, Cornell University, in 2006

- Basel II: Technical Issues 1010 kb Presentation: A Comment. Presented by Sanjiv Das, Santa Clara University, in 2006

- Benchmarking Asset Correlations. Presented by Alfred Hamerle, University of Regensburg, in 2003

- The Bond Pricing Implications of Rating-Based Capital Requirements. Presented by Scott Murray, Georgia State University, in 2019

- Capital Incentives and Adequacy for Securitizations. Presented by Daniel Rösch, University of Hannover, in 2010

- Competitive Effects of Basel II on U.S. Bank Credit Card Lending. Presented by William W. Lang, Federal Reserve Bank of Philadelphia, in 2006

- Countercyclical Contingent Capital (CCC): Possible Use and Ideal Design. Presented by Giuseppe De Martino, Bank of Italy, in 2010

- Deferred Tax Assets and Bank Regulatory Capital. Presented by John Gallemore, University of North Carolina at Chapel Hill, in 2012

- Deposit Rate Advantages at the Largest Banks. Presented by Stefan Jacewitz, FDIC, in 2013

- Dynamic Bank Capital Regulation in Equilibrium. Presented by Andrea Gamba, University of Warwick, in 2017

- Dynamic Bank Capital Requirements. Presented by Tetiana Davydiuk, Carnegie Mellon University, in 2017

- The Effects of Bank Capital Buffers in Bank Lending and Firm Activity: What Can We Learn from Five Years of Stress-Test Results? Presented by: Jose M. Berrospide, Federal Reserve Board in 2019

- Evaluating Internal Credit Rating Systems Depending on Bank Size. Presented by Hergen Frerichs, Goethe-University of Frankfurt, in 2003

- Higher Bank Capital Requirements and Mortgage Pricing: Evidence from the CounterCyclical Capital Buffer. Presented by Christoph Basten, ETH Zurich and FINMA, in 2014

- How Do Financial Institutions React to Tax Increases? Presented by Alexander Schandlbauer, Vienna Graduate School of Finance, in 2013

- The Informativeness of Discretionary LLPs During the Financial Crisis. Presented by Paul Beck, University of Southern Mississippi, in 2016

- Large Capital Infusions, Investor Reactions, and the Return and Risk Performance of Financial Institutions. Presented by Elyas Elyasiani, Temple University, in 2010

- Loan Portfolio Quality and the Diffusion of Technological Innovation. Presented by Robert Hauswald, American University, in 2003

- Proving Approval: Dividend Regulation and Capital Payout Incentives. Presented by Levent Güntay, FDIC, in 2015

- Rational Dividend Addiction in Banking. Presented by Benoit d'Udekem, Université Libre de Bruxelles, Solvay School of Economics and Management, in 2015

- A Reexamination of Contingent Convertibles with Stock Price Triggers. Presented by George Pennacchi, University of Illinois, in 2016

- Risk-Based Capital Requirements for Banks and International Trade: Evidence from Basel II Implementation in Turkey. Presented by Banu Demir, Bilkent University, in 2014 
- The Shadow Cost of Bank Capital Requirements. Presented by Roni Kisin, Washington University in St. Louis, in 2013

- Taxes and Bank Capital Structure. Presented by Glenn Schepens, Ghent University and National Bank of Belgium, in 2013

\section{Credit Risk: Types of Credit Risk and How Banks Respond}

- Banks' Use of Credit Derivatives and the Pricing of Loans: What Is the Channel and Does It Persist Under Adverse Economic Conditions? Presented by Lars Norden, Erasmus University, in 2011.

- CDS and Sovereign Bond Market Liquidity. Presented by Batchimeg Sambalaibat, Carnegie Mellon University, in 2014.

- Common Failings: How Corporate Defaults Are Correlated. Presented by Sanjiv Das, Santa Clara University, in 2004.

- Counterparty Risk in Financial Contracts: Should the Insured Worry About the Insurer? Presented by James R. Thompson, School of Accounting and Finance, University of Waterloo, in 2008.

- Credit Derivatives and the Default Risk of Large Complex Financial Institutions. Presented by Giovanni Calice, University of Bath, School of Management, in 2010.

- Credit Rating Accuracy and Incentives. Presented by Robert Jarrow, Cornell University, in 2009.

- Credit Spread Interdependencies of European States and Banks During the Financial Crisis - PDF. Presented by Adrian Alter, University of Konstanz, in 2011.

- Creditor Rights and Bank Losses: A Cross-Country Comparison. Presented by Gans Narayanamoorthy, Tulane University, in 2018.

- Credit-Rating Shopping, Selection, and the Equilibrium Structure of Ratings. Presented by Francesco Sangiorgi, Stockholm School of Economics, in 2009.

- Did CDS Trading Improve the Market for Corporate Bonds? Presented by Sanjiv Das, Santa Clara University, in 2011.

- Do Credit Rating Agencies Underestimate Liquidity Risk? Presented by Radhakrishnan Gopalan, Washington University in St. Louis, in 2010.

- The Effects of Banking Competition on Growth and Financial Stability: Evidence from the National Banking Era. Presented by Sergio Correia, Federal Reserve Board, in 2018.

- An Empirical Comparison of Credit Spreads Between the Bond Market and the CreditDefault -Swap (CDS). Presented by Haibin Zhu, Bank for International Settlements, in 2004.

- Exploring the Sources of Default Clustering. Presented by S. Azizpour, Apollo Global Management, in 2014.

- Fundamentals-Based versus Market-Based Cross-Sectional Models of CDS Spreads. Presented by Sanjiv Das, Santa Clara University, in 2006.

- Government Guarantees and Banks' Earnings Management. Presented by Felipe Bastos G. Silva, Cornell University, in 2018.

- The Impact of Risk Retention Regulation on the Underwriting of Securitized Mortgages. Presented by Craig Furfine, Northwestern University, in 2018.

- The Information Content of Asset-Backed Securities Downgrades and the Motivation Behind Them. Presented by Eric J. Higgins, Kansas State University, in 2010. 
- Laying off Credit Risk: Loan Sales versus Credit Default Swaps. Presented by Christine Parlour, Haas School of Business, University of California, Berkeley, Andrew Winton, Carlson School of Management, University of Minnesota, in 2008.

- MBS Ratings and the Mortgage Credit Boom. Presented by Adam Ashcraft, Federal Reserve Bank of New York, in 2009.

- Optimal Credit Risk Transfer, Monitored Finance, and Banks. Presented by Gabriella Chiesa, University of Bologna, in 2008.

- The Removal of Credit Ratings from Capital Regulation: Implications for Systemic Risk. Presented by Kathleen Weiss Hanley, University of Maryland, in 2014.

- Risk Management and Rating Segmentation in Credit Markets. Presented by Giacomo Rodano, Bank of Italy, in 2014.

- Testing for Opaqueness in the European Banking Industry: Evidence from Bond Credit Ratings. Presented by Giuliano Iannotta, Università Commerciale Luigi Bocconi, in 2004.

- Understanding the Risk in Synthetic CDOs. Presented by Michael Gibson, Federal Reserve Board, in 2004.

- What Can We Learn About Capital Structure from Bond Credit Spreads? Presented by Mark J. Flannery, University of Florida, in 2006.

\section{Deposit Insurance: Deposit Insurance System Design, Including How Deposit Insurance Affects Bank Behavior}

- Applying Credit Risk Models to Deposit Insurance Pricing: Empirical Evidence from the Italian Banking System. Presented by Aurelio Maccario, Unicredit Banca Mobiliare, in 2003.

- The Cost of Deposit Insurance for Privately Held Banks: A Market Comparable Approach. Presented by Michael Falkenheim, Office of Management and Budget, in 2002.

- Deposit Inflows and Outflows in Failing Banks: The Role of Deposit Insurance. Presented by Manju Puri, Duke University, Federal Deposit Insurance Corporation, and the National Bureau of Economic Research, in 2018.

- Deposit Insurance and Risk Management of the U.S. Banking System: How Much? How Safe? Who Pays? Presented by Andrew Kuritzkes, Oliver. Wyman \& Company, in 2002.

- Deposit Insurance Premiums and Arbitrage. Presented by Edward Kim, University of California at Los Angeles, in 2019.

- Deposit Insurance, Bank Regulation, and Financial System Risks. Presented by George Pennacchi, University of Illinois, in 2005.

- Determinants of Deposit-Insurance Adoption and Design. Presented by Asli DemirgüçKunt, World Bank, in 2005.

- Evaluating the Adequacy of the Deposit Insurance Fund: A Credit-Risk Modeling Approach. Presented by Rosalind Bennett, FDIC, in 2002.

- A General Martingale Approach to Measuring and Valuing Risk to the Deposit Insurance Funds. Presented by Robert Jarrow, Cornell University, in 2003.

- Is Deposit Insurance a Good Thing, and If So, Who Should Pay for It? Presented by Alan Morrison, Saïd Business School, University of Oxford, in 2005.

- The Political Economy of Deposit Insurance. Presented by Luc Laeven, The World Bank, in 2003. 
- Pricing FDIC Insurance Using Reduced Form Credit Risk Models. Presented by Darrell Duffie, Stanford University, in 2002.

- Resolving Failed Banks: Uncertainty, Multiple Bidding \& Auction Design. Presented by Jason Allen, Bank of Canada, in 2019.

- Risk Assessment for Banking Systems. Presented by Helmut Elsinger, University of Vienna, in 2003.

- Risk-Neutralizing a Loss Distribution: Pricing the FDIC's Reinsurance Risk. Presented by Haluk Ünal, University of Maryland, in 2003.

- Systemic Risk, Bank Capital, and Deposit Insurance Around the World. Presented by Denefa Bostandzic, Ruhr-Universität Bochum, in 2014.

- Too-Big-To-Fail or Full Deposit Insurance: Evidence from Turkey. Presented by Zeynep Önder, Bilkent University, in 2003.

- Using Loan Rates to Measure and Regulate Bank Risk: Findings and an Immodest Proposal. Presented by Don Morgan, Federal Reserve Bank of New York, in 2002.

\section{Failures/Resolution: Properties of Bank Resolution Regimes and Policies}

- An Analysis of Closure Policy Under Alternative Regulatory Structures. Presented by Greg Caldwell, Bank of Canada, in 2005.

- Asset Fire Sale or Cherry Picking: Evidence from Commercial REO Sales. Presented by Yongqiang Chu, University of South Carolina, in 2012.

- Bank Bailouts, Competitive Distortions, and Consumer Welfare. Presented by César Calderón, World Bank, in 2012.

- Bank Liability Structure, FDIC Loss, and Time to Failure: A Quantile Regression Approach 292 kb. Presented by Klaus Schaeck, University of Southhampton, in 2006.

- Cash-in-the-Market Pricing and Optimal Resolution of Bank Failure. Presented by Viral V. Acharya, London Business School and CEPR, in 2006.

- Catharsis in the Financial Sector? Tracing the Real Effects of Bank Insolvency and Resolution. Presented by Josef Korte, Goethe University Frankfurt, in 2012.

- Debt Structure and the Protections Offered by Bankruptcy Law to Creditors, Debtors, and the Firm. Presented by Kose John, New York University, in 2012.

- Designing Countercyclical Risk-Based Deposit Insurance. Presented by Haluk Ünal, University of Maryland, in 2006.

- Do Bank Failures Affect Real Economic Activity? State-Level Evidence from the PreDepression Era. Presented by Carlos Ramirez, George Mason University, in 2005.

- Interbank Contagion: Evidence from Real Transactions. Presented by Rajkamal Iyer, INSEAD, in 2005.

- International Evidence on Government Support and Risk-Taking in the Banking Sector. Presented by Luis Brandao-Marques, International Monetary Fund, in 2012.

- Preemptive Distress Resolution Through Bank Mergers. Presented by Ralf Elsas, Goethe-Universität Frankfurt, in 2004.

- Resolving Too Big to Fail. Presented by James Traina, University of Chicago, in 2018.

\section{Financial Crisis: Determinants of the Financial Crisis and the Effects of the Crisis on the Financial System}

- Accounting Discretion of Banks During a Financial Crisis. Presented by Harry Huizinga, Tilburg University, in 2009. 
- The Cleansing Effect of Banking Crises. Presented by Reint Gropp, IWH and University of Magdeburg, in 2018.

- Collateral Circulation and Repo Spreads. Presented by Jeongmin Lee, Smith School of Business, University of Maryland, in 2013.

- Déjà Vu All Over Again: The Causes of U.S. Commercial Bank Failures This Time Around. Presented by Rebel A. Cole, DePaul University, in 2010.

- Did TARP Banks Get Competitive Advantages? Presented by Allen N. Berger, University of South Carolina, in 2013.

- Euro Area Cross-Border Banking: Before and After the Global Financial Crisis. Presented by Pierluigi Bologna, Bank of Italy, in 2013.

- Financial Crisis, Temporary Liquidity Guarantee Program, and Impacts on the Fixed Income Markets. Presented by Brent W. Ambrose, The Pennsylvania State University, in 2012.

- The Fire-Sale Channels of Universal Banks in the European Sovereign Debt Crisis. Presented by Falko Fecht, Frankfurt School of Finance and Management, in 2018.

- Friend or Foe? Cross-Border Linkages, Contagious Banking Crises, and "Coordinated" Macroprudential Policies. Presented by Laura Kodres, International Monetary Fund, in 2018.

- Hedge Fund Stock Trading in the Financial Crisis of 2007-2008. Presented by Itzhak Ben-David, The Ohio State University, in 2010.

- Hot Money as a Transmission Channel of the Global Financial Crisis to Emerging Markets. Presented by Ana-Maria Fuertes, Cass Business School, City University London, in 2013.

- How Did U.S. Banks React to Capital Losses Induced by Real Estate Prices? Presented by Vicente Cuñat, London School of Economics, in 2013.

- How Does Bank Trading Activity Affect Performance? An Investigation Before and After the Crisis. Presented by Michael R. King, University of Western Ontario, in 2013.

- The Redistributive Effects of Financial Deregulation. Presented by Anton Korinek, Johns Hopkins University and NBER, in 2013.

- Safety-Net Benefits Conferred on Difficult-to-Fail-and-Unwind Banks in the U.S. and EU Before and During the Great Recession. Presented by Santiago Carbó-Valverde, University of Granada, Spain, in 2011.

- Searching for a Metric for Financial Stability. Presented by Charles Goodhart, London School of Economics, in 2006.

- Social Networks in the Global Banking Sector. Presented by Joel F. Houston, University of Florida, in 2013.

- This Time Is the Same: Using Bank Performance in 1998 to Explain Bank Performance During the Recent Financial Crisis. Presented by Rüdiger Fahlenbrach, Ecole Polytechnique Fédérale de Lausanne (EPFL), in 2011.

- What Caused the Global Financial Crisis? Evidence on the Drivers of Financial Imbalances 1999-2007. Presented by Ouarda Merrouche International Monetary Fund, in 2010.

- Where's the Smoking Gun? A Study of Underwriting Standards for U.S. Subprime Mortgages. Presented by Geetesh Bhardwaj, The Vanguard Group, in 2009.

- Wishful Thinking or Effective Threat? Tightening Bank Resolution Regimes and Bank Risk-Taking. Presented by Magdalena Ignatowski, Goethe University Frankfurt, in 2013. 
- Is Financial Globalization Beneficial? Presented by Frederic Mishkin, Columbia University, in 2005 .

\section{Fintech: What is "Financial Technology" and How Does it Affect Financial Markets}

- Can Technology Undermine Macroprudential Regulation? Evidence from Peer-to-Peer Credit in China. Presented by Fabio Braggion, Tiburg University, in 2019.

- Crowding Out Banks: Credit Substitution by Peer-to-Peer Lending. Presented by Brian Wolfe, University at Buffalo, in 2017.

- Designing Central Bank Digital Currencies. Presented by Itai Agur, International Monetary Fund, in 2019.

- The Effect of Secondary Market Liquidity on Primary Market Liquidity: A Natural Experiment in Peer-to-Peer Lending. Presented by Craig Holden, Indiana University, in 2019.

- Fintech and Firm Selection: Evidence from E-Commerce Platform Lending. Presented by Ye Li, The Ohio State University, in 2018.

- Fintech Lending: Financial Inclusion, Risk Pricing, and Alternative Information. Presented by Julapa Jagtiani, Federal Reserve Bank of Philadelphia, in 2017.

- Fintech, Regulatory Arbitrage, and the Rise of Shadow Banks. Presented by Gregor Matvos, University of Chicago, in 2017.

- Reintermediation in FinTech: Evidence from Online Lending. Presented by Tetyana Balyuk, Emory University, in 2018.

- Winners and Losers of Marketplace Lending: Evidence from Borrower Credit Dynamics. Presented by Nikhil Paradkar, Georgia Institute of Technology, in 2018.

- The Wisdom of Crowds and Information Cascades in FinTech: Evidence from Initial Coin Offerings. Presented by Tao Li, University of Florida, in 2018.

\section{Governance: What Role Does Governance Play in Moderating Bank Risk}

- Bank CEO Incentives and the Credit Crisis. Presented by Rüdiger Fahlenbrach, Ohio State University, in 2009.

- Bankers' Pay Structure and Risk. Presented by John Thanassoulis, University of Oxford, in 2011.

- Better Safe than Sorry? CEO Inside Debt and Risk-Taking in Bank Acquisitions. Presented by Abhishek Srivastav, University of Edinburgh Business School, in 2013.

- CEO Bonus Compensation and Bank Default Risk: Evidence from the U.S. and Europe. Presented by Jens Hagendorff, The University of Edinburgh, in 2011.

- Corporate Governance and the Hedging Premium Around the World. Presented by George Allayannis, University of Virginia, in 2004.

- Corporate Governance in the Recent Financial Crisis: Evidence from Financial Institutions Worldwide. Presented by David Erkens, University of Southern California, in 2009.

- Credit and Punishment: The Turnover Performance Sensitivity of Wall Street Bankers. Presented by Kristoph Kleiner, Indiana University, in 2017.

- Do Labor Markets Discipline? Evidence from RMBS Bankers. Presented by Gonzalo Maturana, Emory University, in 2017.

- Executive Compensation and Policy Choices at U.S. Commercial Banks. Presented by Robert DeYoung, University of Kansas, in 2009. 
- The Fall of ESO Repricing: Governance Reform or Reform Gone Awry? Presented by N.K. Chidambaran, Rutgers University, in 2004.

- Financial Expertise as an Arms Race. Presented by Vincent Glode, University of Pennsylvania, in 2009.

- Flows, Performance, and Managerial Incentives in Hedge Funds. Presented by Vikas Agarwal, Georgia State University, in 2004.

- The Governance of Banks: How Do Bank Capital and Monitoring Impact Post-Acquisition and Performance. Presented by Christa Bouwman, University of Michigan, in 2004.

- Incentive Effects of Illiquid Stock and Option Holdings of Target and Acquirer CEOs. Presented by Jie Cai, University of Iowa, in 2004.

- Inside Debt, Bank Default Risk, and Performance During the Crisis. Presented by Rosalind L. Bennett, FDIC, in 2013.

- Liberalization, Corporate Governance, and Savings Banks. Presented by Manuel I llueca, Universitat Jaume I, in 2009.

- Managerial Incentives and Risk. Presented by Jeffery Coles, Arizona State University, in 2004.

- Managerial Incentives and the Efficiency of Capital Structure in U.S. Commercial Banking. Presented by Joseph P. Hughes, Rutgers University, in 2003.

- Managerial Incentives in the Presence of Envious Workers. Presented by Konstantinos Tzioumis, Office of the Comptroller of the Currency, in 2009.

- Nonlinear Incentives and Mortgage Officers' Decisions. Presented by Konstantinos Tzioumis, Office of the Comptroller of the Currency, in 2011.

- Regulation, Subordinated Debt, and Incentive Features of CEO Compensation in the Banking Industry. Presented by Kose John, New York University, in 2003.

- Silent Large Shareholders and Entrenched Bank Management: Evidence from the Banking Crisis in Japan. Presented by Masahura Hanazaki, Hitotsubashi University, in 2003.

- Underreporting of Bank Risk: Does Shareholder-Manager Distance Matter? Presented by Thomas Flanagan, University of Michigan, in 2019.

- Whose Private Benefits of Control - Owners or Managers? Presented by Joon Ho Hwang, Indiana University, in 2004.

\section{Household Finance: Aspects of Consumer Borrowing}

- Bhardwaj Credit Booms and Lending Standards: Evidence from the Subprime Mortgage Market. Presented by Giovanni Dell’Ariccia, International Monetary Fund, Deniz Igan, International Monetary Fund, Luc Laeven, International Monetary Fund, in 2008.

- Differences Across Originators in CMBS Loan Performance. Presented by Lamont Black, Federal Reserve Board, in 2010.

- Do Financial Counseling Mandates Improve Mortgage Choice and Performance? Evidence from a Legislative Experiment. Presented by Sumit Agarwal, Federal Reserve Bank of Chicago, in 2009.

- Information Disclosure, Cognitive Biases, and Payday Borrowing. Presented by Marianne Bertrand, University of Chicago, in 2009.

- The Sources of Value of Relationships: Screening, Monitoring, and the Likelihood of Consumer Default. Presented by Manju Puri, Duke University, in 2010. 
- The Subprime Credit Crisis of 07. Presented by Michel Crouhy, Head of Research, Natixis, Robert Jarrow, Johnson Graduate School of Management, Cornell University, Stuart Turnbull, Bauer College of Business, University of Houston, in 2008.

- Your House or Your Credit Card, Which Would You Choose? Personal Delinquency Tradeoffs and Precautionary Liquidity Motives. Presented by Ethan Cohen-Cole, University of Maryland, in 2009.

\section{Lending: Determinants of Bank Lending}

- Access to Credit and Stock Market Participation. Presented by Serhiy Kozak, University of Michigan, in 2015.

- Asset-Backed Securities: Costs and Benefits of "Bankruptcy Remoteness." Presented by Kenneth Ayotte, Columbia Business School, in 2005.

- Bank Capital, Borrower Power, and Loan Rates. Presented by João A. C. Santos, Federal Reserve Bank of New York, in 2010.

- Banks and Bubbles: How Good Are Bankers at Spotting Winners? Presented by Laura Gonzalez, University of Florida, in 2006.

- Borrower-Lender Distance, Credit Scoring, and the Performance of Small Business Loans. Presented by Robert DeYoung, Federal Reserve Bank of Chicago, in 2005.

- Capital Constraints, Asymmetric Information, and Internal Capital Markets in Banking: New Evidence. Presented by Dmytro Holod, SUNY, in 2006.

- Capital Ratios and Bank Lending: A Matched Bank Approach. Presented by Mark Carlson, Board of Governors of the Federal Reserve System, in 2011.

- Changes in the Cost of Bank Equity and the Supply of Bank Credit. Presented by Claire Célérier, University of Toronto, in 2017.

- Credit Card Securitization and Regulatory Arbitrage. Presented by Charles Calomiris, Columbia University, in 2003.

- The Cross-Market Spillover of Economic Shocks Through Multi-Market Banks. Presented by Jose Berrospide, Board of Governors of the Federal Reserve System, in 2011.

- Discount Rate for Workout Recoveries: An Empirical Study. Presented by Brooks Brady, American Express, in 2006.

- Do Bank Branches Still Matter? The Effect of Closings on Local Economic Outcomes. Presented by Hoai-Luu Nguyen, University of California at Berkeley, in 2015.

- Enhancing Loan Quality Through Transparency: Evidence from the European Central Bank Loan Level Reporting Initiative. Presented by Aytekin Ertan, London Business School, in 2016.

- Financial Crisis and the Supply of Corporate Credit. Presented by Santiago Barraza, University de San Andrés, in 2017.

- Foreign Entry and Bank Competition. Presented by Rajdeep Sengupta, Vanderbilt University, in 2005.

- How Committed Are Bank Corporate Line Commitments? Presented by Irina Barakova, Office of the Comptroller of the Currency, in 2012.

- How Committed Are Bank Lines of Credit? Evidence from the Subprime Mortgage Crisis. Presented by Rocco Huang, Federal Reserve Bank of Philadelphia, in 2009.

- The Effect of Banking Relationships on the Future of Financially Distressed Firms. Presented by Claire M. Rosenfeld, Carlson School of Management, University of Minnesota, in 2007. 
- The Effects of Competition on Consumer Credit Markets. Presented by Edison Yu, Federal Reserve Bank of Philadelphia, in 2018.

- The Effects of Informational Frictions on Credit Reallocation. Presented by Olivier Darmouni, Princeton University, in 2016.

- Impact of Higher Capital Buffers on Banks' Lending: Evidence from the Euro Area Experiments. Presented by Giuseppe Cappelletti, European Central Bank, in 2019.

- The Impact of Information Asymmetry on Debt Pricing and Maturity. Presented by Regina Wittenberg-Moerman, Wharton School, University of Pennsylvania, in 2007.

- The Impact of Stress Tests on Bank Lending. Presented by Jose M. Berrospide, Federal Reserve Board, in 2017.

- The Impact of the U.S. Financial Crisis on Global Retail Lending. Presented by Manju Puri, Duke University, in 2009.

- Information or Insurance? On the Role of Loan Officer Discretion in Credit Assessment. Presented by Martin Brown, University of St. Gallen, in 2012.

- Information Sharing and Lender Scope: Evidence from the U.S. Commercial Lending Market. Presented by José Liberti, Northwestern University and DePaul University, in 2016.

- Lending Standards and Output Growth. Presented by Divya Kirti, International Monetary Fund, in 2019.

- Loan Guarantees and Credit Supply. Presented by Natalie Bachas, Princeton University, in 2019.

- Monetary Stimulus and Bank Lending. Presented by Indraneel Chakraborty, University of Miami, Coral Gables, in 2016.

- Nonbank Lending. Presented by Isil Erel, The Ohio State University, in 2018.

- On Loan Sales, Loan Contracting, and Lending Relationships. Presented by Manju Puri, Duke University, in 2006.

- Product Diversification in the European Banking Industry: Risk and Loan Pricing Implications. Presented by Laetitia Lepetit University de Limoges, in 2006.

- The Profit-Credit Cycle. Presented by Björn Richter, University of Bonn, in 2019.

- Regulatory Changes and Bank Equity Risk: The CAPM Cost of Capital and Lending Supply. Presented by Anna Kovner, Federal Reserve Bank of New York, in 2019.

- Risk Overhang and Loan Portfolio Decisions: The Supply of Small Business Loans before and During the Financial Crisis. Presented by Robert DeYoung, University of Kansas, in 2011.

- Rules versus Discretion in Loan Rate Setting. Presented by Geraldo Cerqueiro, Department of Finance, CentER - Tilburg University, in 2007.

- Sector Concentration in Loan Portfolios and Economic Capital. Presented by Klaus Düllmann, Deutsche Bundesbank, in 2006.

- Securities Laws and the Choice Between Loans and Bonds for Highly Levered Firms. Presented by Robert Prilmeier, Tulane University, in 2019.

- Shock Propagation and Banking Structure. Presented by Farzad Saidi, Stockholm School of Economics, in 2017.

- Small Bank Comparative Advantages in Alleviating Financial Constraints and Providing Liquidity Insurance over Time. Presented by Allen Berger, University of South Carolina, in 2015.

- Some Borrowers Are More Equal than Others: Bank Funding Shocks and Credit Reallocation. Presented by Olivier De Jonghe, Tilburg University, in 2016.

- A Theory of Procyclical Bank Herding. Presented by Viral V. Acharya, London Business School, in 2003. 
- Tying Knots: Lending to Win Equity Underwriting Business. Presented by Manju Puri, Duke University, in 2003.

- Unconventional Monetary Policy and Bank Lending Relationships. Presented by Christophe Cahn, Banque de France, in 2017.

- Walking Wounded or Living Dead? Making Banks Foreclose Bad Loans. Presented by Max Bruche and Gerard Llobet, CEMFI, in 2010.

- What Do One Million Credit Line Observations Tell Us About Exposure at Default? A Study of Credit Line Usage by Spanish Firms. Presented by Gabriel Jiménez, Banco de España, in 2006.

- What Drives Global Syndication of Bank Loans? Effects of Capital Regulations. Presented by Janet Gao, Indiana University, in 2018.

- What Is Special About Bank Loans? Presented by Greg Nini, University of Pennsylvania, in 2012.

\section{Liabilities: Aspects of Various Types of Bank Liabilities}

- An Analysis of European Banks' SND Issues and Its Implications for the Design of a Mandatory Subordinated Debt Policy. Presented by Andrea Sironi, Bocconi University, in 2000 .

- The Effect of Monetary Policy on Bank Wholesale Funding. Presented by Dong Beom Choi, Federal Reserve Bank of New York, in 2016.

- Forbearance Expectations and the Subordinated Debt Signal of Bank Insolvency. Presented by Gerald Hanweck George Mason University, in 2002.

- Getting the Most out of a Mandatory Subordinated Debt Requirement. Presented by Rong Fan Case Western Reserve University, in 2002.

- Money in a Theory of Banking. Presented by Raghuram Rajan, University of Chicago, in 2003.

- Paying Attention to Banks: Evidence from Offshore Deposits. Presented by Pablo Slutzky, University of Maryland, in 2018.

- Sub-Debt Yield Spreads as Bank Risk Measures. Presented by Douglas Evanoff (FRB Chicago), in 2000.

- Using Bond and Stock Markets to Monitor Bank Holding Companies: Is It Feasible? Presented by Diana Hancock, Federal Reserve Board, in 2000.

- Why Hire Your Rival? The Case of Bank Debt Underwriting. Presented by David A. Becher, Drexel University, in 2016.

\section{Liquidity: Liquidity Measurement and the Effects of Liquidity Regulation on Financial Stability}

- Are Extreme Negative Liquidity Shocks in the U.S. Equity and Treasury Notes Markets Contagious? Presented by Kuan-Hui Lee, Rutgers Business School, in 2007.

- Bank Liquidity and Capital Regulation in General Equilibrium. Presented by Francisco Covas, Federal Reserve Board, in 2015.

- Bank Liquidity Creation. Presented by Allen N. Berger, Federal Reserve Board, in 2007.

- Capital Regulation, Liquidity Requirements, and Taxation in a Dynamic Model of Banking. Presented by Gianni De Nicoló, International Monetary Fund, in 2012. 
- The Costs and Benefits of Liquidity Regulations: Lessons from an Idle Monetary Policy Tool. Presented by Christopher J. Curfman, University of Texas at Austin, in 2019.

- Designed for Failure? Risk-Return Tradeoffs and Risk Management of Structured Investment Vehicles. Presented by Sanjiv R. Das, Santa Clara University, in 2013.

- Intermediated Asset Prices. Presented by Zhiguo He, Northwestern University, in 2007.

- Limited Market Access and Funding Liquidity. Presented by Zhuo Chen, Kellog School of Management, Northwestern University, in 2013.

- Liquidity Crisis, Runs, and Security Design—Lessons from the Collapse of the Auction Rate Municipal Bond Market. Presented by Song Han, Federal Reserve Board, Dan Li, Federal Reserve Board, in 2008.

- Liquidity Effects in Options Markets: Premium or Discount? Presented by Prachi Deuskar, College of Business, University of Illinois at Urbana- Champaign, in 2007.

- Liquidity Regulation and Financial Intermediaries. Presented by Marco Macchiavelli, Federal Reserve Board, in 2019.

- Liquidity Requirements and Deposit Competition. Presented by Junho Park, Singapore Management University, in 2019.

- Liquidity Trap and Excessive Leverage. Presented by Anton Korinek, Johns Hopkins University, in 2015.

- Loan Sales and Bank Liquidity Risk Management: Evidence from the Shared National Credit Program. Presented by Rustom M. Irani, University of Illinois at Urbana-Champaign, in 2014.

- Market Liquidity, Asset Prices, and Welfare. Presented by Jennifer Huang, McCombs School of Business, University of Texas at Austin, in 2007.

- Measuring Liquidity Mismatch in the Banking Sector. Presented by Jennie Bai, Georgetown University, in 2014.

- A Network View on Money Market Freezes. Presented by Puriya Abbassi, Deutsche Bundesbank, in 2013.

- Precautionary Reserves and the Interbank Market. Presented by Adam Ashcraft, Federal Reserve Bank of New York, in 2007.

- Pushing on a String: Did Borrowing from the Federal Reserve Help Resolve the Financial Crisis? Presented by Allen N. Berger, University of South Carolina, in 2012.

- Risk Taking and Low Longer-Term Interest Rates: Evidence from the U.S. Syndicated Loan Market. Presented by Sirio Aramonte, Federal Reserve Board, in 2014.

- Run Lengths and Liquidity. Presented by Sanjiv R. Das, Santa Clara University, in 2007.

- Systemic Funding Liquidity Risk and Bank Failures. Presented by Han Hong, Stanford University, in 2013.

- Tests of the New Intermediary Asset Pricing Theory: The Role of Lead Bank Capital in the Liquidity of Syndicated Loans. Presented by Allen N. Berger, University of South Carolina, in 2019.

- To Sell or to Borrow? Presented by Michal Kowalik, Federal Reserve Bank of Kansas City, in 2012.

- Unintended Consequences of Post-Crisis Liquidity Regulation. Presented by Suresh Sundaresan, Columbia Business School, in 2019.

\section{Market Discipline/Information: How Market Information Affects Bank Behavior}

- Bank Characteristics and Cyclical Variations in Bank Stock Returns. Presented by Lieven Baele, Ghent University, in 2003. 
- Bank Stability, Transparency, and the Safety Net. Presented by Erlend W. Nier, Bank of England, in 2006.

- Banking Relationships and Conflicts of Interest: Market Reactions to Lending Decisions by Korean Banks. Presented by Wook Sohn, KDI School of Public Policy and Management, in 2005.

- Can Feedback from the Jumbo-CD Market Improve Bank Surveillance? Presented by R. Alton Gilbert, Federal Reserve Bank of St. Louis, in 2003.

- Competition versus Agency Costs: An Analysis of Charter Values in European Banking. Presented by Olivier De Jonghe, Ghent University, in 2005.

- Convertible Bond Arbitrage, Liquidity Externalities, and Stock Prices. Presented by Heather Tookes, Yale School of Management, in 2007.

- Did FDICIA Enhance Market Discipline? A Look at Evidence from the Jumbo CD Market. Presented by John Hall, University of Arkansas, in 2004.

- Do Accounting Changes Affect the Economic Behavior of Financial Firms? Presented by Anne Beatty, Ohio State University, in 2006.

- Do Markets React to Bank Examination Ratings? Evidence of Indirect Disclosure. Presented by Linda Allen (Baruch College, CUNY), in 2000.

- Does the Stock Market Value Bank Diversification? Presented by Lieven Baele, Tilburg University, in 2006.

- Dynamic Depositor Discipline in U.S. Banks. Presented by Kathleen M. McDill, FDIC and Andrea M. Maechler, International Monetary Fund, in 2003.

- The End of Market Discipline? Investor Expectations of Implicit State Guarantees. Presented by Viral V. Acharya, New York University, in 2013.

- How Depositors Discipline Banks: A Micro-Level Case Study of Hamilton Bank. Presented by Andrew Davenport, FDIC, in 2004.

- The Informational Efficiency of the Equity Market as Compared to the Syndicated Bank Loan Market. Presented by Linda Allen, Baruch College, CUNY, in 2005.

- Market Discipline of Banks: The Asset Test. Presented by Donald P. Morgan (FRB NY), in 2000.

- Payoff Complementarities and Financial Fragility: Evidence from Mutual Fund Outflows. Presented by Qi Chen, Fuqua School of Business, Duke University, in 2007.

- Private Information Trading and Enhanced Accounting Disclosure of Bank Stocks. Presented by Rocco Huang, The World Bank and University of Amsterdam, in 2006.

- Setting the Stage: Some Thoughts on 'Market Discipline.' Presented by Mark Flannery University of Florida, in 2000.

- Use of Subordinated Debt in the Supervisory \& Monitoring Process to Enhance Market Discipline. Presented by Douglas Evanoff, Federal Reserve Bank of Chicago, in 2004.

- Using Price Information as an Instrument of Market Discipline in Regulating Bank Risk. Presented by Alfred Lehar, University of Vienna, in 2005.

- What Did the Credit Market Expect of Argentina Default? Evidence from Default Swap Data. Presented by Frank Zhang, Federal Reserve Board, in 2004.

\section{Real Effects: Real Effects of Bank Regulation and Supervision}

- (Inter-State) Banking and (Inter-State) Trade: Does Real Integration Follow Financial Integration? Presented by Tomasz Michalski and Evren Ors, HEC Paris, in 2010.

- Big Banks versus Small Banks: Good or Bad for Industries? Presented by Indrit Hoxha, Pennsylvania State University Harrisburg, in 2010. 
- Did Saving Wall Street Really Save Main Street? The Real Effects of TARP on Local Economic Conditions. Presented by Allen N. Berger, University of South Carolina, Wharton Financial Institutions Center, and European Banking Center, in 2014.

- Do Asset Price Bubbles Have Negative Real Effects? Presented by Indraneel Chakraborty, Southern Methodist University, in 2013.

- The Firm-Level Real Effects of Bank-Scope Deregulation: Evidence from the Rise of Universal Banking. Presented by Daniel Neuhann, University of Pennsylvania Farzad Saidi, University of Cambridge, in 2014.

- The Micro Impact of Macroprudential Policies: Firm-Level Evidence. Presented by Maria Soledad Martinez Peria, International Monetary Fund, in 2018.

- Real Activity Forecasts Using Loan Portfolio Information. Presented by Urooj Khan, Columbia University, in 2014.

- The Real Effects of Capital Requirements: Evidence from the UK. Presented by Filippo De Marco, Bocconi University, in 2015.

- The Real Effects of Credit Line Drawdowns. Presented by Jose M. Berrospide, Federal Reserve, in 2013.

- The Welfare Effects of Bank Liquidity and Capital Requirements. Presented by Skander J. Van den Heuvel, Federal Reserve Board, in 2018.

- Winners and Losers of Financial Crises: Evidence from Individuals and Firms. Presented by Daniela Hochfellner, University of Michigan and IAB, in 2015.

\section{Regulation/Supervision: Forms of Regulation and Supervision and How They Affect Financial Stability}

- Bank Bailouts, Bail-Ins, or No Regulatory Intervention? A Dynamic Model and Empirical Tests of Optimal Regulation. Presented by Raluca A. Roman, Federal Reserve Bank of Philadelphia, in 2018.

- Banks, Taxes, and Nonbank Competition. Presented by George Pennacchi, University of Illinois, in 2015.

- Basel II Has Been a Costly Distraction on the Road to Minimizing the Societal Cost of Bank Failures. Presented by George Kaufman, Loyola University Chicago, in 2006.

- Dressing Up for the Regulators: Evidence from the Largest-Ever Supervisory Review. Presented by Puriya Abbassi, Deutsche Bundesbank, in 2019.

- The Effect of Bank Supervision on Risk Taking: Evidence from a Natural Experiment. Presented by John Kandrac, Federal Reserve Board, in 2017.

- Estimating Changes to Minimum Regulatory Capital Under Basel II's Standardized Approach. Presented by Katherine Wyatt, New York State Banking Department, in 2006.

- Estimating the Value of Good Financial Policies. Presented by Ken Froot, Harvard University, in 2004.

- Foreign Investment, Regulatory Arbitrage, and the Risk of U.S. Financial Institutions. Presented by W. Scott Frame, Federal Reserve Bank of Atlanta, in 2016.

- How Bank Regulation, Supervision, and Lender Identity Impact Loan Pricing: a CrossCountry Comparison. Presented by Li Hao, Schulich School of Business, York University Toronto Canada, in 2005.

- Hub-and-Spoke Regulation and Bank Leverage. Presented by Ankit Kalda, Washington University in St. Louis, in 2017. 
- The Impact of Supervision on Bank Performance. Presented by Beverly Hirtle, Federal Reserve Bank of New York, in 2016.

- Multinational Banks and Supranational Supervision. Presented by Giacamo Calzolari, University of Bologna and CEPR, in 2016.

- Optimal Supervisory Policies and Depositor-Preference Laws. Presented by Henri Pages, Bank of France, in 2003.

- Regulators' Disclosure Decisions: Evidence from Bank Enforcement Actions. Presented by Anna Kleymenova, University of Chicago, in 2019.

- Regulatory Capture and Banking Supervision Reform. Presented by Pierre C. Boyer, University of Mannheim, in 2011.

- The Role of Relative Performance in Bank Closure Decisions. Presented by Kenneth Kasa, Simon Fraser University, in 2003.

- Strategic Avoidance of Supervision. Presented by Ben Ranish, Federal Reserve Board, in 2017.

- Using Securities Market Information for Supervisory Monitoring. Presented by John Krainer, Federal Reserve Bank of San Francisco, in 2003.

\section{Systemic Risk: Contributing Factors to Systemic Risk and How They are Measured}

- Bail-Ins and Bail-Outs: Incentives, Connectivity, and Systemic Stability. Presented by Agostino Capponi, Columbia University, in 2017.

- Bank Capital and Systemic Stability. Presented by Deniz Anginer, Virginia Tech, in 2015.

- Bank Regulation Under Fire Sale Externalities. Presented by Gazi I. Kara, Board of Governors of the Federal Reserve System, in 2016.

- Banks as Regulated Traders. Presented by Antonio Falato, Federal Reserve Board, in 2019.

- Banks' Non-Interest Income and Systemic Risk. Presented by Markus Brunnermeier, Princeton University, in 2011.

- Central Counterparty Default Waterfalls and Systemic Loss. Presented by Samim Ghamimi, UC Berkeley, in 2019.

- Collateral Runs. Presented by Sebastian Infante, Federal Reserve Board, in 2019.

- Cross-Border Bank Flows and Systemic Risk. Presented by G. Andrew Karolyi, Cornell University, in 2016.

- Disclosure, Runs, and Bank Capital Raising. Presented by Jean Helwege, University of California, Riverside, in 2017.

- Discretion and Systemic Risk in Credit-Line Contracts: Theory and Evidence. Presented by Maria Chaderina, WU Vienna University, in 2016.

- Distress Dispersion and Systemic Risk in Networks. Presented by Jessie Jiaxu Wang, Arizona State University, in 2015.

- Endogenous Risk-Exposure and Systemic Instability. Presented by Chong Shu, University of Southern California, in 2019.

- Financial Networks over the Business Cycle. Presented by Alexandr Kopytov, Princeton University, in 2019.

- The Full Story of Runs. Presented by Jun Kyung Auh, Georgetown University, in 2017. 
- Identifying Contagion in a Banking Network. Presented by Filip Zikes, Federal Reserve Board, in 2017.

- Information Contagion and Systemic Risk. Presented by Toni Ahnert, London School of Economics and Political Science and Financial Markets Group, in 2012.

- Measuring and Testing for the Systemically Important Financial Institutions. Presented by Carlos Castro, Universidad del Rosario, Colombia, in 2011.

- Measuring Systemic Risk and Assessing Systemic Importance in Global and Regional Financial Markets Using the ESS-Indicator. Presented by Wolfgang Lahmann, Technische Universitaet München, in 2011.

- Measuring Systemic Risk Contributions. Presented by Xin Huang, University of Oklahoma, in 2010.

- Measuring the Tail Risks of Banks. Presented by Martin Knaup and Wolf Wagner, Tilburg University, in 2010.

- Money Runs. Presented by Jason Roderick Donaldson, Washington University in St. Louis, in 2017.

- Systemic Risk in Clearing Houses: Evidence from the European Repo Market. Presented by Charles Boissel, HEC Paris, in 2014.

- Systemic Risk in Financial Markets: How Systemically Important are Insurers? Presented by Christoph Kaserer, Technische Universitaet Muenchen, in 2016.

- The Systemic Risk of European Banks During the Financial and Sovereign Debt Crises. Presented by Lamont Black, Federal Reserve Board, in 2012.

- Systemic Size, Bank Risk, and Systemic Crises. Presented by Jens Hagendorff, University of Edinburgh, in 2012.

- A System-Wide Approach to Measure Connectivity in the Financial Sector. Presented by Sumanta Basu, University of California Berkeley, in 2016.

- A Tale of Two Runs: Depositor Responses to Bank Solvency Risk. Presented by Rajkamal Iyer, MIT, in 2015.

- Variation in Systemic Risk at U.S. Banks During 1974-2010. Presented by Armen Hovakimian, Baruch College, in 2012.

- Wholesale Funding Runs. Presented by Christophe Perignon, HEC Paris, in 2016.

\section{Appendix 3: Bank Research Conference Keynote Addresses, 2000-2019}

Mark Flannery, University of Florida. Setting the Stage: Some Thoughts on 'Market Discipline'. 2000.

Darrell Duffie, Stanford University. Pricing FDIC Insurance Using Reduced Form Credit Risk Models. 2002.

Robert Jarrow, Cornell University. Pricing FDIC Insurance Using Reduced Form Credit Risk Models. 2002.

Daniel Kahneman, Princeton University. Luncheon Address. 2003.

Raghuram Rajan, Money in a Theory of Banking. 2003.

Richard Syron, Freddie Mac. Luncheon Address. 2004.

Ken Froot, Harvard University. Estimating the Value of Good Financial Policies. 2004.

Frederic Mishkin, Columbia University. Is Financial Globalization Beneficial? 2005.

Diana Taylor, Superintendent of Banks for the State of New York. Lunch Address. 2006.

Charles Goodhart, London School of Economics. Searching for a Metric for Financial Stability. 2006. 
René Stulz, Ohio State University. How Much do Banks use Credit Derivatives to Reduce Risk? 2006.

Francis Longstaff, UCLA. Liquidity Risk: An Overview. 2007.

Kenneth Feinberg, Special Master for Executive Compensation. Luncheon Address. 2009.

Gary Gorton, Yale University. Collateral Crises. 2011.

Anil Kashyap, University of Chicago. Macro-Prudential Regulatory Challenges. 2012.

Jan Krahnen, Goethe Universitat Frankfurt. Structural Reforms and Banking Regulation: Perspectives for the Eurozone. 2013.

René Stulz, Ohio State University. Governance, Risk Management, and Risk-Taking in Banks. 2014.

Andrew Metrick, Yale University. Keynote Address. 2015.

Douglas Diamond, University of Chicago. Liquidity Requirements, Liquidity Choice and Financial Stability. 2016.

Anjan Thakor, Washington University in St. Louis. Bank Culture and Capital. 2017.

Deborah Lucas, Massachusetts Institute of Technology. Bailouts. 2018.

Amit Seru, Stanford University. Regulating Banks in the Era of Fintech Shadow Banks. 2019.

Funding The authors are employed by the Federal Deposit Insurance Corporation.

\section{Declarations}

Competing Interests The authors have no competing interests to declare that are relevant to the content of this article.

\section{References}

Acharya V, Steffen S (2015) The "greatest" carry trade ever? Understanding Eurozone Bank risks. J Financ Econ 115(2):215-236. https://doi.org/10.1016/j.jfineco.2014.11.004

Agarwal V, Daniel N, Naik N (2009) Role of managerial incentives and discretion in hedge fund performance. J Financ 64(5):2221-2256. https://doi.org/10.1111/j.1540-6261.2009.01499.x

Bachelder J (2008) EESA limits on executive pay at affected institutions. New York Law J 14:2008

Baele L, De Jonghe O, Vennet RV (2007) Does the stock market value Bank diversification? J Bank Financ 31(7):1999-2023. https://doi.org/10.1016/j.jbankfin.2006.08.003

Bennett R, Güntay L, Ünal H (2015) Inside debt, Bank default risk, and performance during the crisis. J Financ Intermed 24(4):487-513. https://doi.org/10.1016/j.jfi.2014.11.006

Berger A, Bouwman C (2009) Bank liquidity creation. Rev Financ Stud 22(9):3779-3837. https://doi. org/10.1093/rfs/hhn104

Boyd J, De Nicoló G (2005) The theory of Bank risk-taking and competition revisited. J Financ 60(3):1329-1343. https://doi.org/10.1111/j.1540-6261.2005.00763.x

Brunnermeier M, Dong GN, Palia D (2020) Banks' noninterest income and systemic risk. Rev Corp Financ Stud 9(2):229-255. https://doi.org/10.1093/rcfs/cfaa006

Buchak G, Matvos G, Piskorski T, Seru A (2018) Fintech, regulatory arbitrage, and the rise of shadow banks. J Financ Econ 130(3):453-483. https://doi.org/10.1016/j.jfineco.2018.03.011

Chakraborty I, Goldstein I, MacKinlay A (2020) Monetary stimulus and Bank lending. J Financ Econ 136(1):189-218. https://doi.org/10.1016/j.jfineco.2019.09.007

Coles J, Daniel N, Naveen L (2006) Managerial incentives and risk-taking. J Financ Econ 79(2):431468. https://doi.org/10.1016/j.jfineco.2004.09.004 
DeYoung R, Peng E, Yan M (2013) Executive compensation and business policy choices at U.S. commercial banks. J Financial Quant Analysis 48(1):165-196

Elsinger H, Lehar A, Summer M (2006) Risk Assessment for Banking Systems. Manag Sci 52(9):iv1456. https://doi.org/10.1287/mnsc.1060.0531

Erkens D, Hung M, Matos P (2012) Corporate governance in the recent financial crisis: evidence from financial institutions worldwide. J Corp Finan 18(2):389-411. https://doi.org/10.1016/j.jcorpfin. 2012.01.005

Fahlenbrach R, Stulz R (2011) Bank CEO incentives and the credit crisis. J Financ Econ 99(1):11-26. https://doi.org/10.1016/j.jfineco.2010.08.010

Faulkender M, Kadyrzhanova D, Prabhala N, Senbet L (2010) Executive compensation: an overview of research on corporate practices and proposed reforms. J Appl Corp Finance 22:107-118. https:// doi.org/10.1111/j.1745-6622.2010.00266.x

Federal Deposit Insurance Corporation (2003) FDIC Launches New Center for Financial Research. fdic. gov/news/press-releases/2003/pr11303.html

Gropp R, Mosk T, Ongena S, Wix C (2019) Bank response to higher capital requirements: evidence from a quasi-natural experiment. Rev Financ Stud 32(1):266-299. https://doi.org/10.1093/rfs/hhy052

Hett F, Schmidt A (2017) Bank rescues and bailout expectations: the Erosion of market discipline during the financial crisis. J Financ Econ 126(3):635-651. https://doi.org/10.1016/j.jfineco.2017.10.003

Iannotta G, Pennacchi G, Santos J (2018) Ratings-based regulation and systematic risk incentives. Rev Financ Stud 32(4):1374-1415. https://doi.org/10.1093/rfs/hhy091

Puri M, Rocholl J, Steffen S (2011) Global retail lending in the aftermath of the U.S. financial crisis: distinguishing between supply and demand effects. J Financ Econ 100 (3):556-578. https://doi.org/ 10.1016/j.jfineco.2010.12.001

Srivastav A, Armitage S, Hagendorff J, King T (2018) Better safe than sorry? CEO inside debt and risktaking in Bank acquisitions. J Financ Stab 36:208-224. https://doi.org/10.1016/j.jfs.2018.04.005

Thanassoulis J (2012) The case for intervening in Bankers' pay. J Financ 67(3):849-895. https://doi.org/ 10.1111/j.1540-6261.2012.01736.x

Tzioumisa K, Geeb M (2013) Nonlinear incentives and mortgage officers' decisions. J Financ Econ 107(2):436-453. https://doi.org/10.1016/j.jfineco.2012.08.014

Vallascas F, Hagendorff J (2013) CEO Bonus compensation and Bank default risk: evidence from the U.S. and Europe. J Financ Markets Instit Instrum 22(2):47-49. https://doi.org/10.1111/fmii.12004

Publisher's Note Springer Nature remains neutral with regard to jurisdictional claims in published maps and institutional affiliations. 